\title{
Dune-phase fluvial transport and deposition model of gravelly sand
}

\author{
MAARTEN G. KLEINHANS \\ Utrecht University, Faculty of Geography, Department of Physical Geography, P.O. Box 80115, \\ 3508 TC Utrecht, The Netherlands (Email: m.kleinhans@geog.uu.nl)
}

\begin{abstract}
The importance and role of sorting processes in dune-phase bedload transport and deposition is demonstrated with flume experiments, vibracores from the River Rhine (The Netherlands) and with sediment transport and dune data from the River Rhine. The entrainment and deposition depth of the sediment depend on dune trough levels below the average bed level and therefore on the dune height. As bedload sediment transport depends partly on grain size, it will be dependent upon the relict vertical sorting left in the bed by former discharge waves. The vertical sorting is created by sorting in grain flows on the lee side of dunes and by gravel lag formation in the dune troughs. Based on these principles, a simple reach-representative process model is developed for the prediction of bed sediment reworking, vertical sorting and deposition by dunes. The model is applied to two successive discharge waves of different magnitude, and predicts qualitatively the same vertical sorting characteristics as observed in the vibracores from the River Rhine (The Netherlands) after two successive discharge waves. The effect of the sorting on the sediment transport, and how to include this feedback in future models, is discussed.
\end{abstract}

\section{INTRODUCTION}

\section{Relevance of sediment sorting and scope}

It has been established that sediment transport and deposition in channel beds with sand and gravel entails consideration of the different sediment sizes and their sorting in the river bed (e.g. Klaassen, 1987, 1991; Klaassen et al., 1987; Bridge \& Bennett, 1992; Wilcock, 1993, 2001; Wathen et al., 1995). In sand-gravel-bed rivers with both large dunes and significant grain-size variation, the sediment is sorted during the development, migration and decay of dunes during discharge waves. As sediment transport depends on grain size, the sorted sediment in turn will affect sediment transport rates in the course of a discharge wave. Sorting during deposition and successive entrainment therefore must be linked in morphodynamic models (Kleinhans, 2001). In the past, mathematical, so-called 'active layer' models have been developed to link dune migration, sediment transport and vertical sediment sorting (e.g. Ribberink, 1987). Usually the sediment involved in dune migration is modelled as a single or at best a few active layers, which has the disadvantage that vertical sediment sorting trends related to the dunes cannot be well represented. Recently Parker et al. (2000) developed a mathematical morphological model concept with a continuous (instead of discrete) description of sediment sorting in the dunes and the bed, but could not implement it because a general predictor for the vertical sediment sorting was not available. A generic understanding of vertical sorting mechanisms is important for the further development of morphological models for sand-gravel-bed river channel behaviour. 
This paper describes necessary elements for a predictor of stratigraphy and sorting in channel bed deposits, and the role of dune height variation in this sorting. Furthermore, the effect of this vertical sorting in the channel bed on bedload transport is discussed. Flume experiments and field data from the River Rhine are used to verify concepts of sorting and their relations with transport. A process model is developed for the sorting in the bed, and the necessary elements are identified for a future mathematical model by which both the sorting patterns and the relation between sorting and the bedload transport can be predicted. The model developed is an extension of Klaassen (1987) and Klaassen et al. (1987), which may be applicable in a model like the one described by Parker et al. (2000) for the case of rivers with dunes.

This study is focused on reach-representative conditions and daily averaged sediment transport for three practical reasons: data collection of sediment sorting and sediment transport in the River Rhine were done at these scales, dune population characteristics must be studied over a number of dunes, and morphodynamic models necessary for large-river management often are schematized for these time- and spatial scales.

\section{Cross-bedded deposits and lag deposits}

Two types of deposits are distinguished genetically, according to Boersma et al. (1968), Allen (1970), Ribberink (1987) and Kleinhans (2001): the cross-bedded deposit with an upward fining, and the lag deposit. Cross-bedded deposits are formed by the propagation of dunes by discontinuous grain flows of bedload sediment at the lee side of a dune. The sediment is sorted vertically in the grain flow process (Fig. 1): the gravel is deposited mainly on the lower half of the lee slope, whereas the finer grades are predominantly deposited in the upper half. The result is an upward fining deposit. Allen (1963, 1970), Boersma et al. (1968) and many others found a distinct upward fining within subaqueous dunes in the laboratory and in the field, indicating that sorting in the grain flow plays an important role. Although this sorting principle related to grain flows is well known, a mathematical description of the process is not available. Hunter (1985) studied grain flow
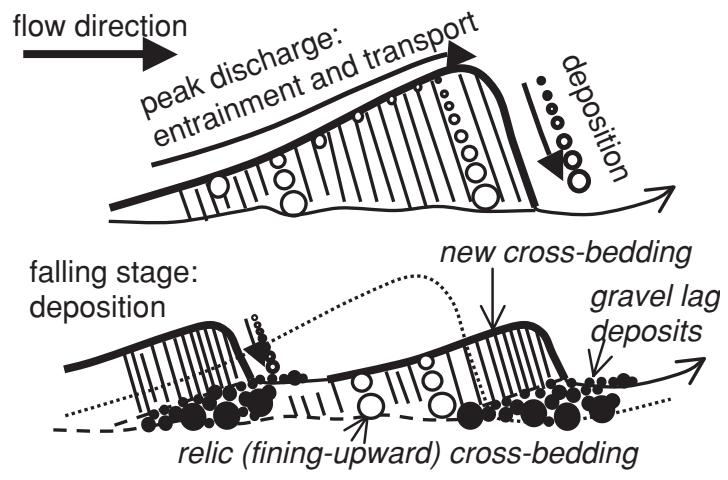

Fig. I Hypothesized channel-bed deposits. During peak discharge the transported sediment is sorted in the grain flows on the lee side of a dune. During waning discharge, the dunes diminish and leave cross-bedding relics. Owing to selective deposition, an upward fining accumulation of lag deposits is created in addition.

dynamics but referred only to well-sorted sand. Jopling (1965) developed a model for the composition of foresets and toesets as a result of settling from suspension at the lee side of a laboratory delta, but focused mainly on conditions with significant suspension, which probably is not relevant for the gravelly sand under study here. When the deposition on slipfaces is dominated by suspension, vertical sorting may disappear or even become coarsening upward (Hunter, 1985).

This study is limited to grain-flow-dominated conditions, which reasonably can be assumed to play a key role in rivers with coarse sediment. Makse et al. (1997) and Koeppe et al. (1998) created stratification and vertical sorting in a bimodal mixture of sand and sugar (in air), and were able to model the sorting patterns. The fining upward pattern was caused by kinematic sorting on the slipface, in which the small grains move downward through the pores of the dilated sediment mixture on the top of the slipface, but the large grains cannot move down. The large grains then are on top of the slipface and have more opportunity to roll down the slope over the small grains. In their models and experiments, however, the cross-stratification and fining upward sorting seem to exclude each other, which raises the question whether their models could be applied to natural sediments and conditions (see Kleinhans (2002) for an extensive review). Kleinhans (2002) 
determined fining upward sorting in a crossstratified subaqueous delta deposit formed in natural sediments in a narrow flume. It was observed that kinematic sorting indeed caused the large grains to emerge on the top of grain flow on the slip face, and this process dominated the sorting even in significant suspension of the finer grades. Contrary to the experiments of Makse and Koeppe, the net sorting in the delta was distinctly fining upward.

Lag deposits are formed as a result of sizeselective entrainment and deposition during the different stages of a discharge wave. The winnowing of fine and intermediate grades from the bed and their reworking into dunes leads to a lag layer consisting of the coarsest grades that were not in motion (Carling et al., 2000). In addition, the largest grains that are in motion during the peak discharge will be deposited in lowering discharge, whereas smaller grains remain in transport. This results in an upward fining accumulation of lag deposits without cross-bedding. Obviously the process of sorting in grain flows on the lee side of dunes may help to transfer the coarser grades down into the active layer (Fig. 1). However, if cross-stratification cannot be observed in deposits because of disturbance in the sampling procedure or because the sediment is too coarse for crossstratification, then it is impossible to distinguish between the gravelly layers formed by grain flows and lag deposits. The importance of these two sorting mechanisms and resulting deposits will be demonstrated in the next sections.

\section{Sediment transport and sorting during and after successive discharge waves}

These sorting patterns are erased and recreated by the dunes of a next discharge event, down to the depth of the deepest troughs of the new dunes. For discharge waves in order of decreasing magnitude, the lower part of their deposits may therefore be preserved. Suppose that two successive discharge waves rework the river bed (no measurable net aggradation or degradation), and the first discharge wave is a large one (e.g. recurrence interval of $10 \mathrm{yr}$ or so, panel 2 in Fig. 2) and the second is smaller (panel 4 in Fig. 2). The resulting deposit (panel 5) may consist of two lag layers, one at the trough depth of dunes which occurred in the first discharge wave (panel 3), and one at the trough depth of the second. In between and above the lag
Fig. 2 Conceptual model of sediment erosion and deposition with emphasis on the role of dunes in two successive discharge waves in order of decreasing magnitude. The vertical sorting (here only the gravel lag layers are shown) is as described in Fig. 1. The smaller dunes of the second discharge wave erase part of the sorting resulting from the first wave, and leave a comparable but less deep vertical sorting.
River bed sorting model with dunes in two discharge waves

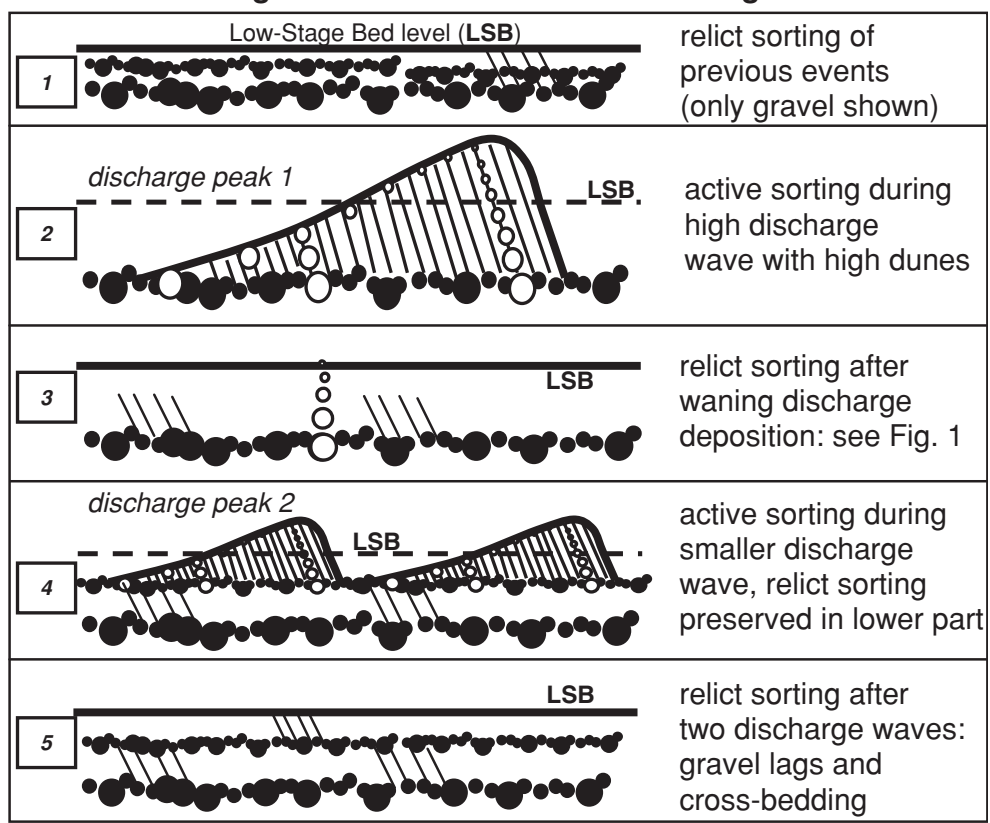


layers, the channel bed may consist of both crossbedded and lag deposits. In Fig. 2, only the lag layers are shown, which are the hypothesized result of two successive discharge waves of which the second one was smaller than the first one. Note that consideration of an inverse order of discharge waves (first small ones then a large one) is not useful for studying the deposits, because then the deposits of the small ones are erased and reworked by the large one.

Dunes are fluctuations of the local bed level around the average bed level. Assuming no net deposition or erosion, the latter is equal to the low-flow plane-bed level. The deepest dune troughs locally determine the depth or lowest level of gravel deposition or entrainment in the bed. The variation in dune height and dune-trough-scour depth may be large (Paola \& Borgman, 1991; Leclair, 2000; Leclair \& Bridge, 2001), thus there may only be a few deep troughs during a certain period of time. Expressed alternatively, it takes a long time and many dune passages before the gravel has uniformly been worked down to (or entrained from) the depth of the deepest troughs (Ribberink, 1987). Thus, on a reach-representative length scale $(c .1 \mathrm{~km})$, with rather regular dunes that move at best a few dune lengths during a discharge wave, and during the non-equilibrium conditions of a discharge wave, the deepest troughs are not likely to dominate the vertical sorting pattern but occur only locally. In that nonequilibrium case, the average or some measure between the average and deepest dune trough depths is more representative of the depth of scour and gravel deposition than in the cases studied, for example, by Leclair (2000) and Leclair \& Bridge (2001). As the sediment transport and deposition on a reach-representative scale are of interest here, the average dune height with concurrent average scour depth is assumed to be representative. An appropriate active layer is then defined here as the layer of moving dunes (represented by their average dimension) in which the sediment is sorted during the time of dune passage (e.g. Ribberink, 1987; Klaassen, 1991). This concept is only a slight simplification of that of Paola \& Borgman (1991) Leclair \& Bridge (2001) and Parker et al. (2000) because in the non-equilibrium conditions considered here the impact of the deepest troughs is extremely limited. Had the discharge waves in the Rhine been longer, then the concept here would be oversimplified. Further consequences of using the average dune dimensions are discussed later.

Hypothesizing, the bedload transport during a discharge wave will be affected by gravelly layers deposited in a previous event as follows:

1 in rising discharge, the dunes attempt to lower their troughs through a relict gravelly layer, which may reduce the natural variation in trough scour depth;

2 as a consequence, this gravel is being incorporated in the active layer;

3 thus the sediment available for transport (i.e. active layer) is relatively coarse, and the bedload transport rate consequently is relatively small;

4 in lowering discharge, the gravel is worked down deeper into the active layer by the grain flow process and in the form of lag deposits;

$\mathbf{5}$ as the dunes become lower and rework an increasingly shallower active layer, the gravel layers are abandoned and the active layer becomes finer;

6 as a result of the fining of the active layer, the bedload rate in falling stages is relatively larger than in rising stages, leading to a hysteresis of bedload rate as a function of discharge.

The bedload transport (capacity) in turn affects the sorting of the bed. If the transport capacity of gravel is high enough to transport all available gravel in the dune layer, then a gravel layer in the dune troughs will not be very thick. Thus bedload transport capacity, availability of sediment in the dune layer and vertical sorting in the deposits are intimately linked.

\section{FLUME EXPERIMENTS}

The concepts introduced in the previous section are in part demonstrated with controlled laboratory experiments. Three experiments have been carried out recently (T5, T7 and T9; in Blom \& Kleinhans, 1999; Kleinhans, 2000, Kleinhans \& Van Rijn, 2002) with a slightly bimodal sandgravel mixture $\left(D_{5}=0.1 \mathrm{~mm}, D_{50}=1.8 \mathrm{~mm}, D_{100}=\right.$ $16 \mathrm{~mm}$ ), which was dredged from the field site in the River Rhine that is described below, and cutoff at $16 \mathrm{~mm}$ to prevent choking of the sediment recirculation system. The flume was $50 \mathrm{~m}$ long 
Table I Basic data from flume experiments presented by Kleinhans \& Van Rijn (2002) and Blom \& Kleinhans (1999).

\begin{tabular}{|c|c|c|c|c|c|}
\hline Number & Condition* & $\begin{array}{l}\text { Hydraulic } \\
\text { radius† }(\mathrm{m})\end{array}$ & $\begin{array}{l}\text { Discharge } \\
\left(m^{3} s^{-1}\right)\end{array}$ & $\begin{array}{l}\text { Flow velocity } \\
\left(\mathrm{m} \mathrm{s}^{-1}\right)(\mathrm{Q} / A)\end{array}$ & $\begin{array}{l}\text { Water surface } \\
\text { slope }\left(10^{-3}\right)\end{array}$ \\
\hline T5 & Selective transport & $0.19-0.23$ & $0.22-0.26$ & 0.69 & -1.472 \\
\hline T7 & All grain sizes in motion & $0.30-0.32$ & $0.4 I-0.43$ & 0.79 & -1.520 \\
\hline T9 & Selective transport & $0.22-0.25$ & $0.26-0.28$ & 0.70 & -1.694 \\
\hline Number & $\begin{array}{l}\text { Grain shear } \\
\text { stress }(\mathrm{Pa})\end{array}$ & $\begin{array}{l}\text { Total bedload } \\
\text { transport } \ddagger \\
\left(\mathrm{g} \mathrm{s}^{-1} \mathrm{~m}^{-1}\right)\end{array}$ & $\begin{array}{l}\text { Gravel§ } \\
\text { fraction in } \\
\text { bedload (\%) }\end{array}$ & $\begin{array}{l}\text { Dune height } \ddagger \\
\left(10^{-3} \mathrm{~m}\right)\end{array}$ & Final bed state \\
\hline T5 & 2.0 & $42.0 \pm 0.4$ & 21 & $28 \pm 11$ & Small barchans over armour layer \\
\hline T7 & 2.3 & $66.0 \pm 0.8$ & 25 & $57 \pm 21$ & Large dunes over armour layer \\
\hline T9 & 2.0 & $50.8 \pm 0.6$ & 18 & $49 \pm 21$ & Large dunes over buried armour layer \\
\hline
\end{tabular}

* Initial condition: bed was mixed and bedslope installed at $-1.400 \times 10^{-3}$.

tCorrected for side-wall roughness with the Vanoni-Brooks method.

¥Given with standard deviations (67th percentiles).

$\S$ Gravel is defined as $D>2 \mathrm{~mm}$. In the sediment put into the flume the gravel fraction is $40 \%$. Values have been determined

from average sieve curve of bed and recirculated sediments and have a standard error of $\pm 0.2 \%$.

and $1.5 \mathrm{~m}$ wide and had electromagnetic bed and water surface profilers that were automatically moved along the flume during the experiments. Basic data are given in Table 1. Uniform flow conditions were maintained to avoid large-scale erosion and sedimentation. The transported sediment was recirculated and the submerged weight in transport measured every few minutes. The standard errors in measuring sediment transport rates are less than $3 \%$. The tests were continued until a morphological equilibrium was reached (change became smaller than noise), which took a few days. The flow, sediment transport and dune parameters were determined by averaging all measurements (sediment transport in the recirculation, fixed flow discharge, water surface and bed profiles over the downstream half of the flume) during the equilibrium phase of the experiments.

The main difference between the experiments is their history. Experiments T5 and T9 had approximately the same flow conditions $\left(0.7 \mathrm{~m} \mathrm{~s}^{-1}\right)$, whereas T7 had a larger flow velocity of $0.8 \mathrm{~m} \mathrm{~s}^{-1}$. The bed shear stresses were just above the initial motion threshold of the coarsest sediment sizes for T7 (but not for T5 and T9), whereas suspension of sand was negligible. Whereas T5 starts from a fully mixed bed, T9 initially has the history of sorting from T5 and T7. This leads to a different final sorting for T9 although the flow velocity was the same as in T5. In T5, the preferential entrainment of sediment finer than the bulk bed sediment led to the formation of a continuous armour layer at the level of dune troughs below the propagating dunes (Fig. 3) (Kleinhans, 2000). Furthermore the sediment was vertically sorted in the dunes. T7 had higher dunes, while the armour at the level of the troughs was lowered due to the winnowing of the extra sediment used to increase the dune volume. Due to the higher shear stress of T7, the entrained sediment also was coarser than in T5. Comparable findings are presented by Klaassen et al. (1987) and Klaassen (1991). In T9 the largest particles from the dunes of T7 were only partially or no longer mobile. This led to a decrease of the dune height and deposition in the dune troughs. Thus the armour layer of the previous experiment was buried below a growing lag deposit of fine gravel (fining upward), seen in Fig. 3 as a fining upward trend below the dune trough level of T9.

The transport rate and composition are affected by the sorting in the bed, as revealed by sediment transport measurements. The sediment transport and the fraction of gravel in transport were highest in T7, and were considerably different in T5 and T9 despite their equal flow velocities (Kleinhans \& Van Rijn, 2002). The sediment transport in T9 was $15 \%$ higher than in $\mathrm{T} 5$, whereas the fraction of gravel in T9 was about the same factor lower 


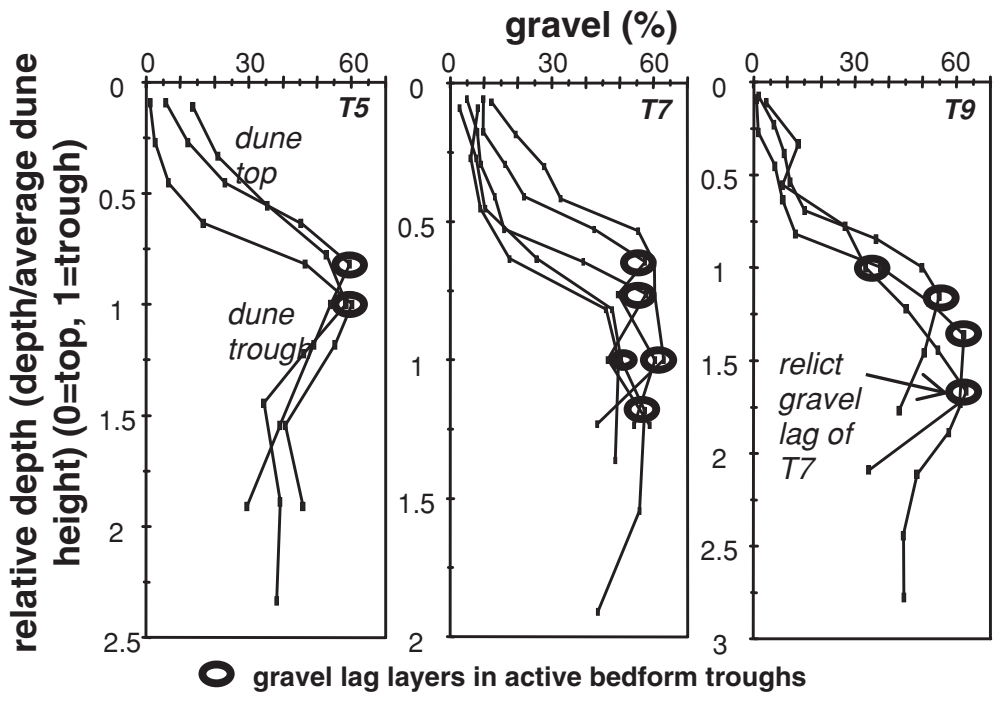

Fig. 3 Vertical sorting measured in the dunes in the flume experiments (Kleinhans, 2000), expressed as the gravel fraction in the sediment ( $D_{\text {gravel }}>2 \mathrm{~mm}$, remainder is sand). The depths of the dune troughs (and armour layers in $\mathrm{T} 5$ and $\mathrm{T} 7$ ) are given as circles. The gravel fraction clearly decreases to the dune top (upward fining). For T9 there is also a relict upward fining deposit below the dune trough level, which consists of relict cross-bedding and the accumulation of lag deposits (Fig. 1). (Data from Blom \& Kleinhans, 1999.)
(Table 1). The entrained gravel of T5 and T7 was deposited in the troughs of the dunes in $\mathrm{T} 9$, and of course the finer sediment of T9 was more easily transported. This was also found by Klaassen et al. (1987) and Klaassen (1991). The experiments showed that a coarse layer is left in the bed that reflects the level of the troughs of the highest dunes in the recent past. The duration of the experiments and the two-dimensionality of the dunes allowed the vertical sorting to attain approximate equilibrium, thus the observed gravel lag layer was plane and continuous at its base, with some cross-stratification of $\mathrm{T} 7$ preserved above it.

\section{DATA FROM THE RIVER RHINE}

\section{Field site description}

The effect of successive discharge waves on reach-representative vertical sorting and sediment transport is studied with data collected in the River Rhine, using vibracores of the channel bed (Gruijters et al., 2001), statistics on dune dimensions and migration rates in 1995 and 1998, as well as suspended and bedload sediment transport during the discharge wave in 1998 (Wilbers, 1998, 1999; Kleinhans, 1999, 2000; Kleinhans \& Ten Brinke, 2001). These datasets were all collected near the bifurcation Pannerdensche Kop, where the Bovenrijn splits into a large branch, the River
Waal (two-thirds of the discharge), and a small branch, the Pannerden Channel (one-third of the discharge, Fig. 4). The Rhine upstream of the bifurcation point is called Bovenrijn. The sediment at that point consists of sand and gravel with $D_{50}=2 \mathrm{~mm}$ and $D_{90}=14 \mathrm{~mm}$. The basic data for 1998 are given in Table 2. In 1995 the largest discharge wave of the past two decades occurred, in 1997 a small discharge wave occurred, and in 1998 a larger one occurred, and between 1998 and the moment of vibracoring, no significant discharge wave occurred (the discharge was determined daily from water levels and calibrated relations between discharge and water level throughout the years).

\section{Dune height and sediment transport measurements}

The dune dimensions were obtained from threedimensional echo soundings. The echo soundings of 1998 were also used for dune tracking to estimate the bedload transport rate from the propagation and dimensions of the dunes with the method of Ten Brinke et al. (1999). Both the bedload sampling method with the Helley-Smith-type sampler and the dune tracking method in 1998 show small bedload transport rates (of sand plus gravel) at rising stage and large transport at falling stage (Fig. 5), i.e. a considerable hysteresis. At falling stage the transport measured with the Helley- 
Fig. 4 Map of the measurement positions of direct sampling of the sediment transport and flow in the River Waal and of dune tracking in the Waal and Bovenrijn, as well as the vibracore positions. The whole area shown in detail was mapped with multibeam echo-sounders.

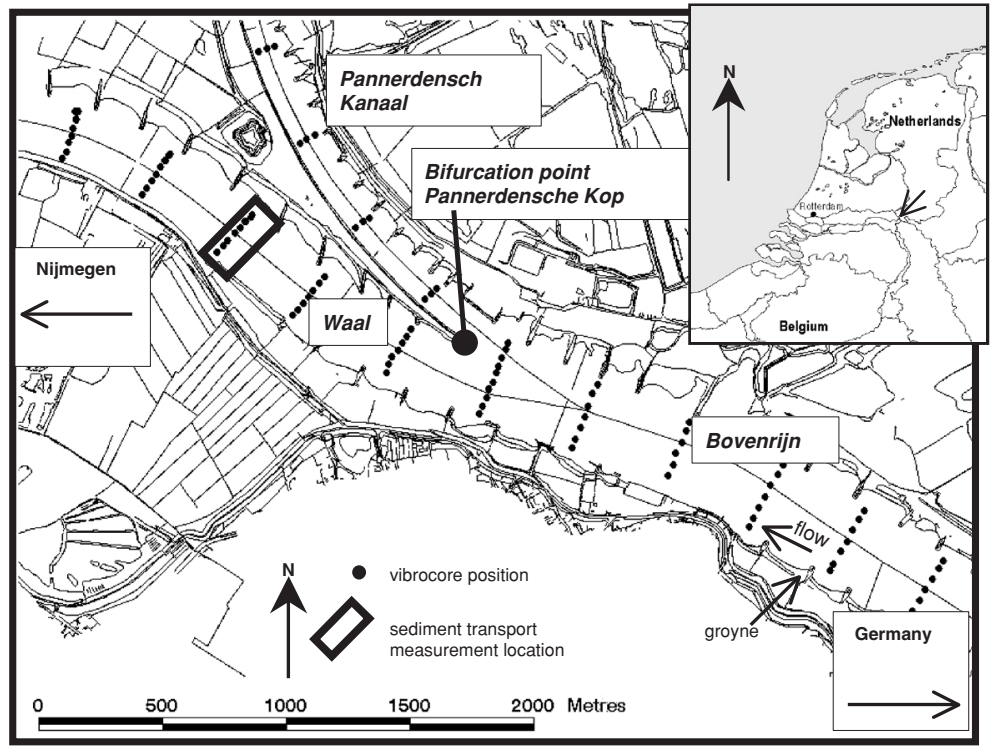

Ten Brinke, 2001). No significant degradation or aggradation of the measurement location could be detected from the echo-soundings.

The dunes were observed to become inactive at falling stage, and small secondary dunes emerged on top of the large primary dunes while reworking and smoothing the tops of the primary dunes. This phenomenon has been observed by others in large rivers and has been attributed to the tardy reaction of large dunes to fast changes in discharge, although a more physical explanation is still wanting (e.g. Allen \& Collinson, 1974). Interestingly, the phenomenon is much more prominent in the Waal than in the upstream Rhine. This may be related to the mobility of the sediment, of which the diameter is only slightly larger in the upstream Rhine whereas the flow discharge is 1.5 times as large. Given the rather slow migration celerity of the large dunes relative to their own length and their becoming inactive, much of the sediment in these dunes was not reworked in the remainder of the discharge wave. Thus the opportunity for preservation of upward fining cross-stratified deposits is considerable (Fig. 1) in the whole area. In general, the bedforms are much smaller than expected from empirical relations between water depth and dune height, which may be due to the non-equilibrium conditions and the presence of groynes. 


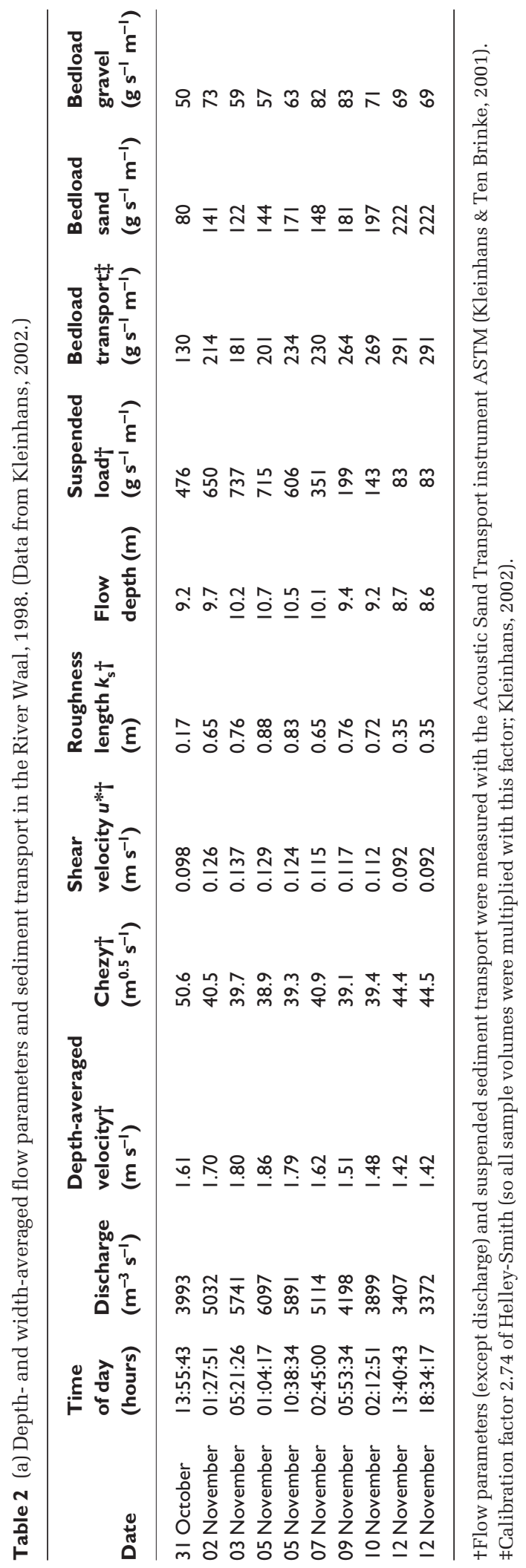


Table 2 (b) Dune parameters and bedload transport from dune tracking in the Waal and Bovenrijn, 1998. (Data from Wilbers, 1999; also see Kleinhans, 2002.)

\begin{tabular}{|c|c|c|c|c|c|c|c|}
\hline & $\begin{array}{l}\text { Discharge } \\
\left(\mathrm{m}^{-3} \mathrm{~s}^{-1}\right)\end{array}$ & $\begin{array}{l}\text { Dune } \\
\text { height } \\
\text { (m) }\end{array}$ & $\begin{array}{l}\text { Dune height } \\
\text { variation } \\
\text { (95\% interval) } \\
\text { (m) }\end{array}$ & $\begin{array}{l}\text { Dune } \\
\text { length } \\
(\mathrm{m})\end{array}$ & $\begin{array}{l}\text { Dune } \\
\text { celerity } \\
\left(\mathrm{m} \mathrm{day}^{-1}\right)\end{array}$ & $\begin{array}{l}\text { Dune } \\
\text { track } \\
\left(\mathrm{m}^{2} \mathrm{day}^{-1}\right)\end{array}$ & $\begin{array}{l}\text { Bedload } \\
\text { transport* } \\
\left(\mathrm{g} \mathrm{s}^{-1} \mathrm{~m}^{-1}\right)\end{array}$ \\
\hline Date & Waal & & & & & & \\
\hline 30 October & 3166 & 0.12 & $0.11-0.14$ & 3.29 & 250 & 3 & 59 \\
\hline 31 October & 4056 & 0.12 & $0.11-0.13$ & 3.93 & 210 & 3 & 55 \\
\hline 2 November & 5363 & 0.22 & $0.20-0.25$ & 6.76 & 70 & 5 & 76 \\
\hline 3 November & 5946 & 0.34 & $0.32-0.37$ & 8.39 & 93 & 14 & 233 \\
\hline 4 November & 6168 & 0.47 & $0.43-0.50$ & 10.87 & 73 & 15 & 261 \\
\hline 5 November & 6002 & 0.53 & $0.47-0.59$ & 13.09 & 59 & 14 & 233 \\
\hline 6 November & 5536 & 0.53 & $0.47-0.58$ & 17.75 & 45 & 12 & 197 \\
\hline 7 Novembert & 4863 & 0.49 & $0.43-0.54$ & 8.65 & 80 & 13 & 217 \\
\hline 10 November & 3770 & 0.30 & $0.27-0.32$ & 6.57 & 130 & 17 & 290 \\
\hline 12 November & 3436 & 0.29 & $0.27-0.32$ & 6.31 & 105 & 14 & 240 \\
\hline I3 November & 3267 & 0.28 & $0.26-0.30$ & 6.07 & 105 & 14 & 243 \\
\hline I6 November & 3045 & 0.31 & $0.29-0.34$ & 5.98 & 119 & 17 & 287 \\
\hline \multirow[t]{2}{*}{19 November } & 3042 & 0.20 & $0.19-0.22$ & 5.58 & 110 & 7 & 126 \\
\hline & $\begin{array}{l}\text { Discharge } \\
\left(\mathrm{m}^{3} \mathrm{~s}^{-1}\right)\end{array}$ & $\begin{array}{l}\text { Dune } \\
\text { height } \\
\text { (m) }\end{array}$ & $\begin{array}{l}\text { Dune height } \\
\text { variation } \\
\text { (95\% interval) } \\
\text { (m) }\end{array}$ & $\begin{array}{l}\text { Dune } \\
\text { length } \\
(\mathrm{m})\end{array}$ & $\begin{array}{l}\text { Dune } \\
\text { celerity } \\
\left(\mathrm{m} \mathrm{day}^{-1}\right)\end{array}$ & $\begin{array}{l}\text { Dune } \\
\text { track } \\
\left(\mathrm{m}^{2} \mathrm{day}^{-1}\right)\end{array}$ & $\begin{array}{l}\text { Bedload } \\
\text { transport* } \\
\left(\mathrm{g} \mathrm{s}^{-1} \mathrm{~m}^{-1}\right)\end{array}$ \\
\hline Date & Bovenrijn & & & & & & \\
\hline 30 October & 4783 & 0.34 & $0.32-0.36$ & 7.84 & 120 & 19 & 313 \\
\hline 31 October & 6180 & 0.48 & $0.44-0.5$ I & 10.97 & 61 & 18 & 311 \\
\hline 2 November & 8119 & 0.72 & $0.66-0.77$ & 15.99 & 57 & 20 & 341 \\
\hline 3 November & 9045 & 0.90 & $0.84-0.97$ & 19.99 & 55 & 22 & 379 \\
\hline 4 November & 9464 & 0.98 & $0.90-1.06$ & 21.92 & 51 & 22 & 378 \\
\hline 5 November & 9149 & 1.07 & $0.98-1.17$ & 24.30 & 41 & 20 & 337 \\
\hline 6 November & 8267 & 1.13 & $1.03-1.23$ & 26.03 & 31 & 16 & 264 \\
\hline 7 November & 7273 & 1.19 & $1.09-1.29$ & 29.16 & 25 & 13 & 223 \\
\hline I0 November & 5640 & 0.92 & $0.83-1.02$ & 32.30 & 18 & 8 & 128 \\
\hline 12 Novembert & 5122 & 0.27 & $0.22-0.32$ & 6.80 & 108 & 12 & 205 \\
\hline I3 November & 4851 & 0.26 & $0.22-0.30$ & 6.68 & 110 & 12 & 204 \\
\hline I6 November & 4522 & 0.29 & $0.26-0.32$ & 6.60 & III & 14 & 239 \\
\hline 19 November & 4527 & 0.23 & $0.21-0.25$ & 7.52 & 96 & II & 181 \\
\hline
\end{tabular}

*Unit of transport ( $\mathrm{g} \mathrm{s}^{-1} \mathrm{~m}^{-1}$ ): grammes per second per metre width. Density of sediment including pores is $1460 \mathrm{~kg} \mathrm{~m}^{-3}$. +Small dunes become active (and large inactive) on 7 November in the Waal and on 12 November in the Bovenrijn. From this date on, the parameters of the small dunes are given.

The bedload sediment was slightly bimodal (like the bed material), with mode diameters of $0.5 \mathrm{~mm}$ for sand and $10 \mathrm{~mm}$ for gravel, allowing a convenient division between sandy and gravelly at $2 \mathrm{~mm}$. The bedload at rising stage consisted of $60 \%$ sand and $40 \%$ gravel, whereas it became sandier during falling stages, with the sand content rising to $75 \%$ near the end of the discharge wave (Kleinhans, 1999, 2000). Thus, the bedload transport was larger after the discharge peak than 
before. This relative rise was solely due to the absolute rise in rate of sand transport, since the rate of gravel transport decreased after the discharge peak.

\section{Explanations for hysteresis of transport rate}

The hysteresis observed in the River Rhine is much larger than that observed in the flume experiments, and larger than can reasonably be expected from differences in grain sizes (bedload predictors are not overly sensitive to grain size). It is likely that other factors amplify the hysteresis. The possible causes of this hysteresis are discussed in detail in Kleinhans (2002) and are summarized here. For lack of more definite data or modelling, the explanations remain hypothetical to some extent. However, a key point to be kept in mind is that in the Rhine upstream of the bifurcation point, the hysteresis in bedload (measured with the dune-track method) was opposite to that in the lower Rhine branch, which considerably limits the possibilities. The causes of hysteresis are probably as follows.

1 Hysteresis of hydraulic roughness owing to dune development (cf. Allen \& Collinson, 1974) may contribute to the transport hysteresis as follows. The tardy reaction of large dunes to changing flow causes a time lag (i.e. hysteresis) between dune height and flow discharge. Thus the dune height is temporarily larger after the discharge peak than before. The energy that is available for the bedload transport is the difference between the total energy (total bed shear stress) and the energy dissipated by dunes, whereas higher dunes generally dissipate more energy. At some point after the discharge peak, secondary dunes emerge superimposed on the primary dunes (Kleinhans, 2002), and are no longer destroyed as they arrive at the top and lee side of the primary dunes. This means that there is probably no flow separation related to the primary dunes and that their hydraulic roughness is negligible. Thus the hydraulic roughness is lower than it was before the discharge peak, and there is more energy available for the transportation of bedload after the discharge peak, leading to counter-clockwise hysteresis of the bedload transport rate. The suspended load transport on the other hand is the largest before the discharge peak (clockwise hysteresis) because the suspension depends on the turbulence generation by dunes.

2 Vertical sorting of bedload sediment in the dunes combined with the dune height development resis causes hysteresis as follows. Because the dune height is lagging behind the discharge, the bed shear stress in falling stages is lower than it was before the discharge peak at the same dune height. Owing to the lower bed shear stress, the gravel is worked down to form a lag deposit. As the dunes further diminish in height, this gravel layer is abandoned. As a result, the sediment in the active layer is finer than it was before the discharge peak. This leads to higher sediment transport rates after the peak than before, i.e. counter-clockwise hysteresis.

3 The erosion of fine sediment from sand deposits below the active river bed upstream of the measurement section may lead to hysteresis as follows. This fine sediment moves downstream as a sand wave, and is more easily transported than the sand-gravel mixture in the active river bed. Depending on the arrival time of the sand wave (and thus the measurement location), clockwise or counter-clockwise hysteresis of bedload results. The origin of the sand wave could be from lowflow sand deposits in the upstream meander pool or sediment derived from an (unknown) bank collapse or gravel mining activity upstream, but this was unfortunately not observed. It is unlikely that the sand was mobilized from between the groynes, as echo-sounding and flow and concentration measurements show that sand enters these areas during high discharge and leaves it during low discharge (Schans, 1998). It is also unlikely that the sand originates from suspension fall-out after the discharge peak, because the concentrations are far too low to contribute a significant volume of sand (Kleinhans, 2002).

Presumably all these hypotheses together are responsible for some part of the hysteresis. The first hypothesis should be tested with a mathematical turbulence model for flow over dunes, which is outside the scope of this paper. The second and third potentially explain the observed fining of bedload sediment. Only the last hypothesis, however, is able to explain why the hysteresis in the Rhine branch (Bovenrijn) upstream of the bifurcation point is opposite to that in the lower branch (Waal). Unfortunately, there are no measurements 
that could indicate the plausibility of a migrating sand wave, therefore this hypothesis remains unfounded for the time being. As neither of the processes responsible for the hysteresis are incorporated in the model presented in this paper, it is not expected that the hysteresis of bedload transport, especially the sandy part of it, is correctly hindcast by the model.

\section{Gravelly layers in the Rhine}

In the Waal, 42 vibracores were collected and in the Bovenrijn 35 (Fig. 4). The total depth of the vibracores commonly exceeded $3 \mathrm{~m}$ depth below the low stage plane bed. From the measured dune height, the likely depth of gravel lag deposition below the low stage bed level (LSB) can be estimated. This estimate will be compared here with the observed depth of gravelly layers in the cores. When the vibracores were taken, the relict dune tops of previous discharge waves had been smeared out completely and the river bed was plane. Thus, the level of the troughs and expected gravelly layers is 0.5 times or slightly more the dune height below the LSB. With the echosoundings, no measurable net erosion or aggradation was found. The coarse layers from the trough levels of the largest dunes of 1995 and 1998 are thus predicted at 0.5 to 0.6 times the dune height below the top of the vibracores (Table 3 ).
The depths of the bottom of the gravelly layers below the top of the cores were measured, rounded to $0.1 \mathrm{~m}$ precision, and are given as frequency distributions for the Waal and the Bovenrijn (Fig. 6). Two maxima are found in both the Bovenrijn and the Waal roughly at the expected depth of the dune troughs (Fig. 6 \& Table 3). It is deemed unlikely that the dunes of only the 1998 event were the cause of this bimodal pattern of gravelly layers, because then the bimodality is unexpected for this large number of vibracores (also see Fig. 7, where the scour depth distribution is clearly unimodal). It is therefore concluded that these layers were deposited by the dunes of 1995 and 1998. There is considerable variation in gravel layer depth around each maximum, which is probably due to trough scour depth variation.

The bimodal distribution of gravel layers was reproduced in experiments with dunes in a sediment mixture in fast changing discharges carried out at St Anthony Falls Laboratory in Minneapolis (USA) (Kleinhans, 2002). In that case, there was no overlap at all between the gravel layer distributions in depth of the two subsequent discharge waves. It is acknowledged that planar gravel layers could also be the lowest part of cross-stratified deposits truncated at a few grain diameters thickness, but the grain size of the planar gravel layers was considerably larger than in the overlying
Table 3 Predicted and observed reach-averaged depths (in $\mathrm{m} \pm 0.1 \mathrm{~m}$ ) below the low-stage bed level of gravel layers in the Rhine branches for two successive discharge waves.

\begin{tabular}{|c|c|c|c|c|c|c|}
\hline \multirow{3}{*}{$\begin{array}{l}\text { Year of } \\
\text { discharge } \\
\text { wave }\end{array}$} & \multicolumn{3}{|c|}{ Bovenrijn } & \multicolumn{3}{|l|}{ Waal } \\
\hline & \multirow{2}{*}{$\begin{array}{l}\text { Dune } \\
\text { height }\end{array}$} & \multicolumn{2}{|c|}{ Gravel-layer depth } & \multirow{2}{*}{$\begin{array}{l}\text { Dune } \\
\text { height }\end{array}$} & \multicolumn{2}{|c|}{ Gravel-layer depth } \\
\hline & & Predicted & Observed & & Predicted & Observed \\
\hline 1995 & 1.5 & 0.8 & 0.7 & $1.4 *$ & $0.7^{*}$ & 0.7 \\
\hline 1998 & 1.2 & 0.5 & 0.3 & 0.6 & 0.3 & 0.3 \\
\hline
\end{tabular}

*In 1995 no dune height measurements were done in the Waal. The dune height used here is estimated from the measured dune heights in 1993, during a comparable discharge wave (Wilbers, 1998). The maximum reach-representative dune height in the Waal was $0.6 \mathrm{~m}$ in 1998. The maximum reach-representative dune height in the Bovenrijn was $1.0 \mathrm{~m}$ in 1998 and $1.5 \mathrm{~m}$ in 1995. In 1995 no echo-soundings were done at the measurement location but from measurements carried out in 1993 at more or less the same discharge peak both upstream and downstream of the measurement location, a probable reach-representative daily maximum dune height of $1.4 \mathrm{~m}$ is obtained. 

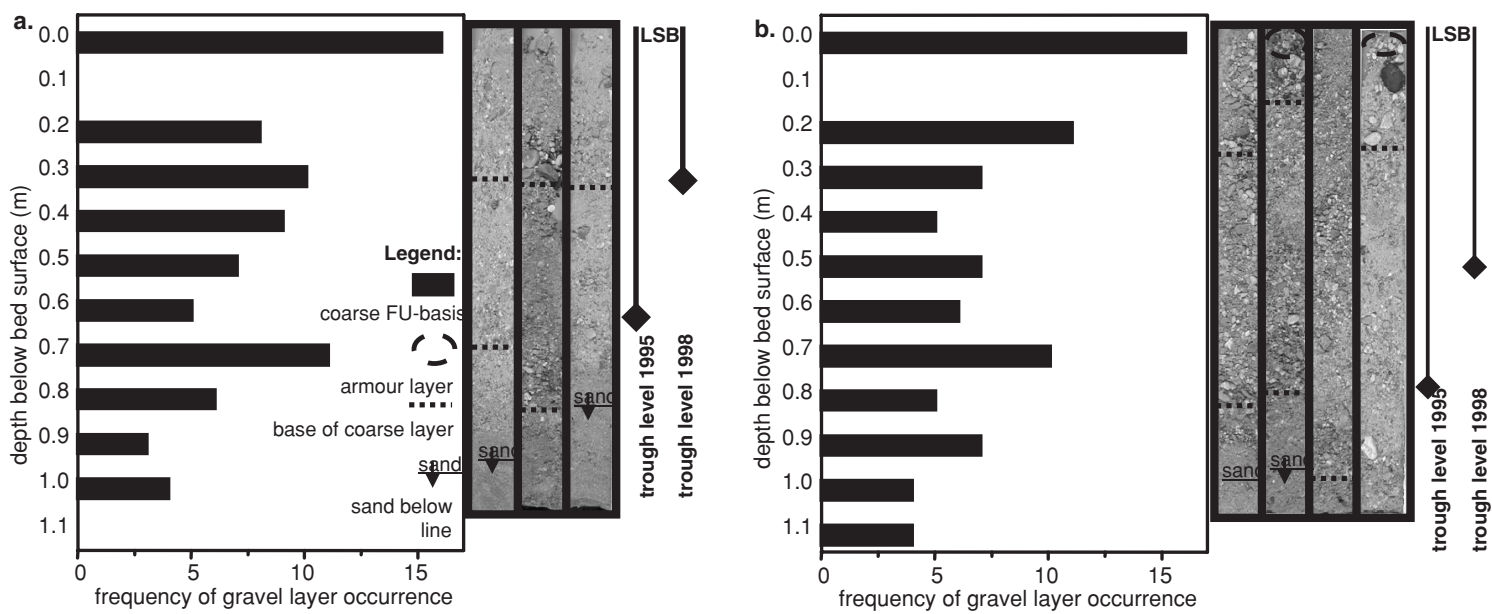

Fig. 6 Observations of the deposits in the River Waal (a) and Bovenrijn (b). The depths of the gravelly layers were measured and used for the histograms (given as the frequency of gravel layer occurrence in the total number of borings used: 35 in Bovenrijn and 42 in Waal). A few examples of vibracores are given, which show the gravel layers. The gravel layers at the bed surface are armour layers, whereas the lower gravel layers are interpreted as the bases of relict cross-bedding and lag deposits (Fig. 1). The lower gravel layers are dominantly found at the depth of dune troughs observed during the discharge waves of 1995 and 1998 (Fig. 2).

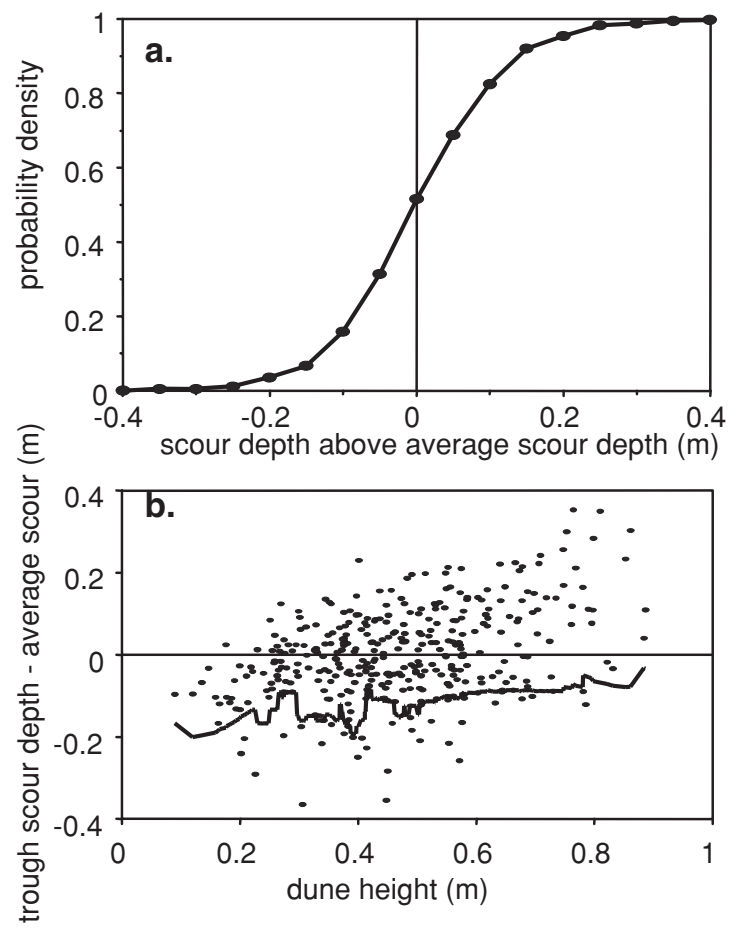

sediment (sudden change of grain size in depth), indicating a lag origin.

The observations of both planar gravel layers of a few grains thick and of fining-upward crossstratification corroborate that the vertical sorting was generated by both sorting mechanisms as described in the introduction. This indicates the importance of the dune height adaptation time and dune celerity. On the one hand, there

Fig. 7 (left) Statistics of dune scour depth of 417 dunes at positions varying from $-100 \mathrm{~m}$ to $+100 \mathrm{~m}$ along the river axis over a $0.5 \mathrm{~km}$ stretch of the River Waal on 4 November (peak discharge). The average dune height was about $0.5 \mathrm{~m}$. The deviation of scour depth of individual dunes above or below the average scour depth is determined by subtracting the moving average over 10 dunes (to remove the large-scale morphology) from the individual scour depth. (a) Probability distribution of the deviation of scour depth.

(b) Deviation of scour depth as a function of dune height (dots). The line denotes the 90th percentile of deepest trough scours calculated from a moving bin of 20 dunes on the list of all dunes ordered from small to large dune height. 
are dunes that adapt slowly to changing flow, and become inactive in lowering discharge (Allen \& Collinson, 1974; Wilbers, 1998, 1999). In this case, truncated primary cross-bedding of the relict dunes and secondary cross-bedding of the troughinfills by secondary dunes are both preserved, as well as lag deposits that vary in thickness in the flow direction (thin below relict dunes and thick below trough-infills). On the other hand, for dunes that adapt very quickly to changing flow (no significant hysteresis), for instance in flume experiments, the secondary cross-bedding will not occur, but cross-bedding and fining-upward lag deposits will be preserved.

The experiments with dunes in a sediment mixture in fast changing discharges carried out at St Anthony Falls Laboratory in Minneapolis (USA) (Kleinhans, 2002) show that this effect indeed occurs, but that the lag deposits and primary foreset deposits for the experimental conditions occur much more frequently in the bed than the fine secondary cross-bedding. This suggests that the effect of the secondary cross-bedding is not of first-order importance. The vibracores of the River Rhine show a considerable variation in grain size and sorting, but the core-spacing is much larger than the dune length and it is not clear whether the variation is the result of the primary and secondary cross-bedding or has other causes such as sorting of sediment in the meander bends. The question of importance of the secondary crossbedding in the Rhine therefore remains unresolved.

\section{Effect of variability of dune height and scour depth on gravel-lag-layer depth}

The statistics of the trough level (comparable to the term scour depth in Leclair \& Bridge, 2001) have been determined from the longitudinal profiles of dunes on 4 November 1998 (peak discharge) (Fig. 7). Three-dimensional dunes are more irregular than two-dimensional dunes and therefore have deeper troughs every now and then. According to the bedform stability diagrams of Southard \& Boguchwal (1990), dunes become more three-dimensional with increasing flow velocity. Using the data from the peak discharge in the Waal ensures that the dunes are as near the condition for three-dimensional dunes as they will get in the River Waal. The coordinates of the dune troughs were determined with the software described earlier. A moving average of 10 trough scour depths was subtracted from each individual (mid-point) scour depth to obtain normalized trough scours. The normalized trough scours were used to compute the trough scour probability distribution (Fig. 7 first panel). In addition, the individual normalized trough scour depths are shown as a function of the concurrent dune height (Fig. 7 second panel).

Only $10 \%$ of all dunes scour more than $0.13 \mathrm{~m}$ below the average scour depth of the surrounding 10 dunes. This variation encompasses at best two classes in the histogram of gravel layer depth (Fig. 6). In addition, the reach-representative statistics are of interest here, although individual deep scours do not propagate fast enough to cover major parts of the river reach. As pointed out earlier, this means that the dune height and scour depth variation is not very relevant for the modelled depth of gravel deposition in this case, where the depths of the gravel layers from the two events are sufficiently far apart.

According to Leclair \& Bridge (2001), the average cross-set thickness is approximately onethird (1 over $2.9[ \pm 0.7]$ ) times the dune height. For a dune height of $0.5 \mathrm{~m}$ this yields cross-sets of $[1 /(2.9-0.7)=0.45 \times 0.5 \mathrm{~m}] 0.23 \mathrm{~m}$ thickness for scour depths that are one standard deviation (67th percentile) larger than the average scour depth. The 10th percentile of scour depth of the dunes in the Waal, however, is less than $0.2 \mathrm{~m}$ below the average scour depth. It therefore must be concluded that the scour-depth variation, and therefore cross-set thickness, in the Waal is considerably less than predicted with the Leclair \& Bridge (2001) parameter. Indeed double gravel lag layers with a distance of about $0.1 \mathrm{~m}$ or more were only observed in about $10 \%$ of the cores in the Waal; in most cases only one gravel lag layer was observed at the level created by a single discharge event.

Figure 7 shows that the deepest scour depths are not necessarily related to the largest dunes. The $10 \%$ deepest scours are only $0.1 \mathrm{~m}$ extra below the average scour depth for the largest dunes, whereas this is $0.2 \mathrm{~m}$ for the average and smaller dunes. Thus the slightly smaller dunes in the dune train may more often have deeper scour holes than the largest dunes. 


\section{PROCESS MODEL OF VERTICAL SORTING}

\section{Model description}

A process model for the prediction of vertical sorting in the river bed is described below. It predicts the potential for the formation of gravel lag layers and the fining upward pattern in channel deposits as a result of two discharge waves. The cross-bedding is assumed to be preserved over the full depth of the active layer in the bed (details explained below), except when a certain portion of the active layer is filled with lag deposits (from base upwards). A highly simplified method for the prediction of lag deposits is followed here. From flow parameters, the bedload transport capacity of that flow is predicted with the method of Kleinhans \& Van Rijn (2002). The bedload transport sediment composition is compared with that of the active layer at the same moment. If there is more gravel present in the active layer than can be transported by the flow, then the difference is potentially available for the formation of a gravel lag layer. The objective for modelling is to hindcast the sorting in the River Rhine for the discharge waves of 1995 and 1998, and determine the relative importance of cross-bedding and gravel lag layer deposits.

This model is only intended to predict the sediment sorting in the channel bed and serves to illustrate the potential importance of gravel lag layers in the channel deposits, but cannot be used for accurate quantitative modelling of the sediment transport. The reason is that bedload predictors always predict that bedload sediment is finer than bed sediment (except for extremely high discharges). If this process were allowed to continue for a long time, the model concept presented here would eventually work down all the gravel into a lag layer, which is not realistic. Therefore the model is not allowed to do this, and the potential gravel lag layer is predicted from the composition of the whole active layer (including the mobile and immobile gravel of the previous time step) in every time-step.

Furthermore, in this model it is assumed that the gravel lag layer forms instantaneously, and is (for increasing dune height) instantaneously entrained into transport in the next time-step.
Obviously the deposition and entrainment processes take time in reality. In point of fact, the entrainment of a gravel lag layer by growing dunes may be so difficult that it causes the previously discussed hysteresis of bedload transport. The bedload transport computation in the model will not give hysteresis, because this effect is not incorporated in this simplified process model. Thus, the 'potential' nature of the gravel lag layer is emphasized here.

The model (Fig. 8) (i) computes flow parameters, (ii) predicts the dune height, (iii) derives the active layer from the dune height, (iv) sorts the sediment vertically in the active layer, (v) predicts the bedload transport from the grainrelated shear stress and the sediment in the active layer, and (vi) deposits the gravel that cannot be transported in a lag deposit at the base of the active layer.

The active layer thickness is calculated from the (average) dune height $(H)$ as $0.5 H$. The choice of the average dune height (rather than the 90th percentile of the dune height distribution as representing the deepest scour depth) is evaluated later. The dune height is usually observed to lag behind the discharge wave: the dune height before the discharge peak is smaller than after the discharge peak, leading to a hysteresis. The dune height is therefore predicted including this hysteresis of dune height as follows. During rising discharge, the reach-averaged dune height is computed with an empirical predictor derived from measurements of 1995, 1997 and 1998 discharge waves at this location:

$$
H_{\text {rise }}=h 0.025\left(D_{50} / h\right)^{0.3} T^{1.7} \quad \text { (in m) }
$$

For falling discharge the dune height predictor of Van Rijn (1993) appears to do well and is used:

$$
H_{\text {fall }}=h 0.11\left(D_{50} / h\right)^{0.3}\left(1-\mathrm{e}^{-0.5 T}\right)(25-T)
$$

(in $\mathrm{m}$ ) in which $D_{50}$ is the median grain size of the average bed sediment. The transport parameter $T$ (Van Rijn, 1984) is given as $T=\left(\tau^{\prime}-\tau_{\mathrm{cr}}\right) / \tau_{\mathrm{cr}}$ (dimensionless), with $\tau_{\text {cr }}$ based on the Shields criterion of the $D_{50}$ of the average bed sediment. Although the trend of the dune height during lowering discharge is thus predicted well, the dune height itself is systematically overpredicted in the Waal. The reason is the time needed for adaptation of the dune dimensions; the actual 

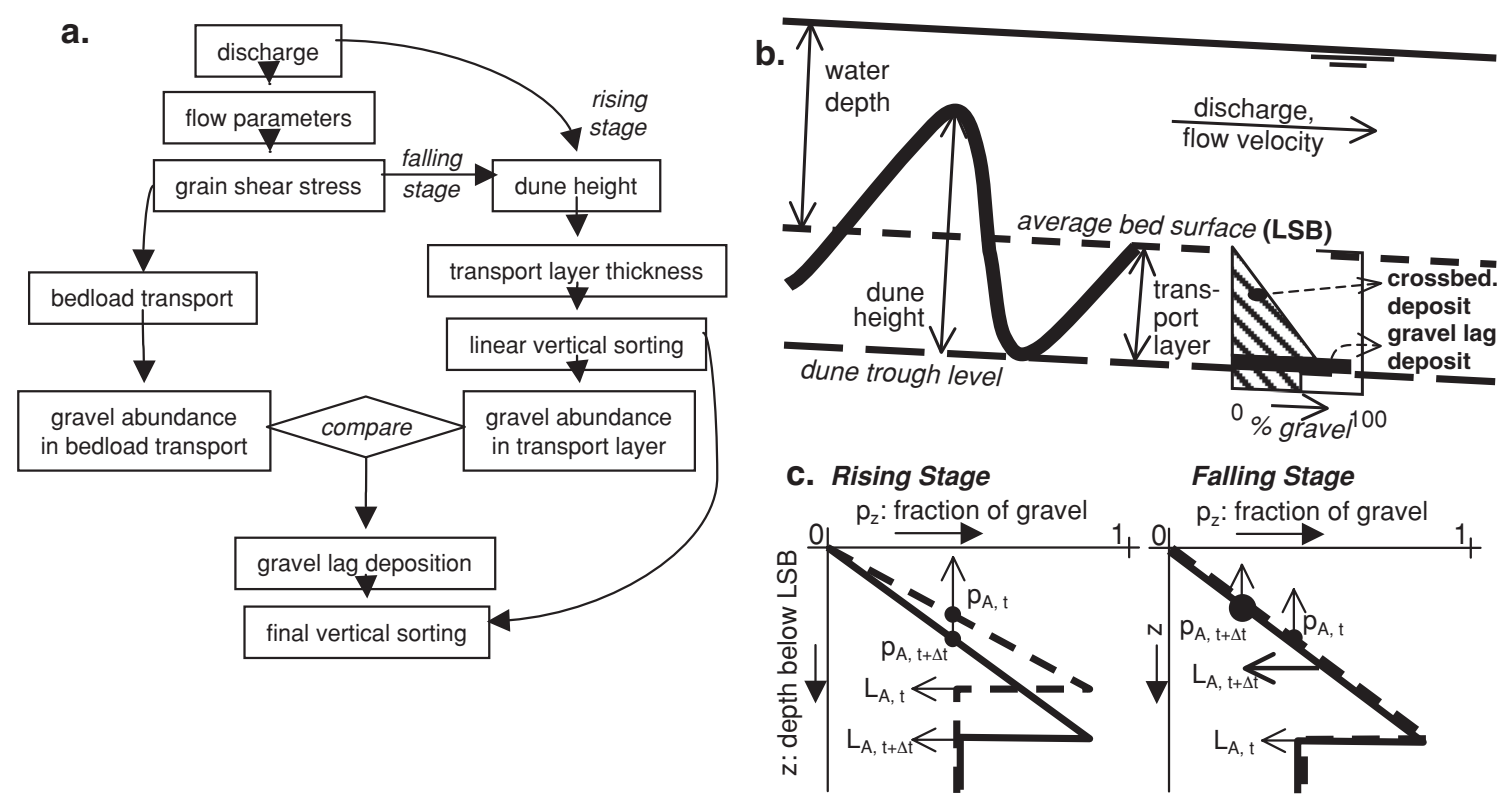

Fig. 8 (a) The structure of the process model for bedload transport and vertical sorting. (b) A sketch of the principal parameters. (c) The different response of cross-bedded sorting in the model in the rising and the falling stages. In the rising stage, the sorting is worked down deeper in the bed, whereas in the falling stage, only the active part of the antecedent sorting is reworked, leading to the same sorting curve, but a lower gravel abundance in the active layer $\left(p_{\mathrm{A}, \mathrm{t}+\Delta \mathrm{t}}\right)$. Other notations are explained in the text.

dune height attained at the discharge peak is lower than the equilibrium dune height at the same discharge. Therefore the second expression for dune height is matched to the first to give the same dune height at peak discharge by adjusting the constant factor (0.11).

The grain shear stress $\tau^{\prime}$ is based on the grain roughness computed from the White-Colebrook equation in which the Nikuradse grain roughness length is given as $k_{\mathrm{s}}^{\prime}=D_{90}=0.012 \mathrm{~m}$ with the $D_{90}$ of the average bed sediment. This method, which is also used in the transport prediction, has been shown to work well on the Rhine sediment (Kleinhans \& Van Rijn, 2002). Alternative methods (e.g. Engelund \& Hansen, 1967 (in Van Rijn, 1993); McLean et al., 1999) would predict the dunerelated shear stress and subtract this from the total shear stress (from the depth-slope product), but in dune-dominated conditions such as those of the Rhine, the small residual grain shear stress would have an unacceptably large uncertainty owing to errors in the dune-related roughness predictors and water surface slope measurements.

\section{Sorting modelling}

Two depositional units are modelled: the crossbedded deposit with a linear upward fining sorting (linear decrease of gravel content in upward direction), and the lag deposit (deposit of gravel only). In the model, the average bed level (equal to the initial plane bed level) is at vertical coordinate $z=0$ (Fig. 8), and $z$ is positive in the downward direction. For simplicity, the sediment is represented in only two grain-size fractions (i): sand and gravel, where $D_{\mathrm{i}}$ refers either to the sand or the gravel fraction. The sand abundance ( $p_{\text {sand }}$, $p=$ fraction, $100 p=$ percentage) is by definition $p_{\text {sand }}=1-p_{\text {gravel }}$. In the model, only the gravel fraction is actually computed.

The grain-related shear stress and the $D_{50}$ and gravel abundance in the active layer are the input parameters for the prediction of bedload transport for each size fraction with a Meyer-Peter \& Mueller (1948) type predictor, adapted for grainsize fractions and hiding-exposure effects, and accounting for near-bed turbulence according to 
Kleinhans \& Van Rijn (2002). The chosen hidingexposure function (Egiazaroff, 1965) was shown to represent the effects well in the flume experiments with Rhine sediment described earlier, and therefore is assumed to be representative for the measurement location as well.

Initially, a completely uniform distribution of gravel in the vertical direction in the bed is assumed:

$$
\mathrm{d} p_{\mathrm{z}} / \mathrm{d} z=0
$$

in which $p$ is the fraction of gravel. The active layer thickness $\left(L_{\mathrm{A}}\right)$ at time $t$ is computed from:

$$
L_{\mathrm{A}, \mathrm{t}}=0.5 H_{\mathrm{t}}
$$

Now the available gravel is linearly distributed over the depth of the active layer $\left(L_{\mathrm{A}}\right.$ below $\left.z=0\right)$ with:

$$
\mathrm{d} p_{\mathrm{z}} / \mathrm{d} z=p_{\mathrm{A}, \mathrm{t}} /\left(0.5 L_{\mathrm{A}, \mathrm{t}}\right)
$$

in which $p_{\mathrm{A}, \mathrm{t}}$ is the depth-averaged gravel fraction in the active layer at time $t$. The factor 0.5 determines that the gravel fraction at $z=0.5 L_{\mathrm{A}, \mathrm{t}}$ is equal to $p_{\mathrm{A}, \mathrm{t}}$ because the depth-averaged gravel fraction in a linear distribution is by definition equal to $p_{\mathrm{z}}$ at $z=0.5 L_{\mathrm{A}, \mathrm{t}}$. Obviously, this only works for gravel fractions smaller than $50 \%$, which is the case in the application of this model in this paper. Otherwise, the additional constraint is that $0<p_{z}<1$ for all $z$. The use of a linear sorting function is justified by flume experiments devised to measure vertical sorting resulting from grain flows in natural sediments (Kleinhans, 2002).

In time, the dune height and active layer thickness change. In the active layer at $t+\Delta t$, only the sediment in the new active layer is assumed to be entrained from the sorted bed from the previous time-step. To calculate the depth-averaged gravel fraction $\left(p_{\mathrm{A}}\right)$ of the new active layer, the gravel abundance $\left(p_{\mathrm{z}, \mathrm{t}}\right)$ is therefore averaged over the depth of the new active layer at $t+\Delta t$ :

$$
p_{\mathrm{A}, \mathrm{t}+\Delta \mathrm{t}}=1 / L_{\mathrm{A}, \mathrm{t}+\Delta \mathrm{t}} \int_{\mathrm{z}=0}^{L_{A, t+\Delta t}} p_{\mathrm{z}, \mathrm{t}}
$$

Now the vertical sorting $\left(p_{\mathrm{z}}\right)$ in the channel bed at $t+\Delta t$ is computed as:

$$
\begin{gathered}
p_{\mathrm{z}, \mathrm{t}+\Delta \mathrm{t}}=p_{\mathrm{z}, \mathrm{t}} \quad \text { for } z>L_{\mathrm{A}, \mathrm{t}+\Delta \mathrm{t}} \\
p_{\mathrm{z}, \mathrm{t}+\Delta \mathrm{t}}=z \mathrm{~d} p_{\mathrm{z}, \mathrm{t}+\Delta \mathrm{t}} / \mathrm{d} z=z p_{\mathrm{A}, \mathrm{t}+\Delta \mathrm{t}} /\left(0.5 L_{\mathrm{A}, \mathrm{t}+\Delta \mathrm{t}}\right) \\
\text { for } z>L_{\mathrm{A}, \mathrm{t}+\Delta \mathrm{t}}
\end{gathered}
$$

in which equation (7) accounts for antecedent gravel abundance below the active layer, and equation (8) accounts for the linearly distributed gravel that is sorted anew for time $t+\Delta t$.

Now the gravel lag layer can be modelled. First, the bedload sediment transport rates of sand, gravel and total (sum of sand and gravel) are predicted, based on the depth-averaged fractions, using $p_{\mathrm{A}, \mathrm{t}+\Delta \mathrm{t}}$ for gravel and $1-\left(p_{\mathrm{A}, \mathrm{t}+\Delta \mathrm{t}}\right)$ for sand. The gravel abundance $f_{\mathrm{A}, \mathrm{g}}$ that potentially can be transported by the flow (and depth-averaged in the active layer) is computed with:

$$
f_{\mathrm{A}, \mathrm{g}}=q_{\mathrm{b}, \text { gravel }} / q_{\mathrm{b}, \text { total }}
$$

in which the bedload transport $q_{\mathrm{b}}$ for sand and gravel is computed with the bedload predictor described in the previous section for each time step $t$. The gravel that is potentially transported by the flow can now be compared with the gravel actually present in the active layer, to find the gravel fraction $p_{\mathrm{L}}$ that will potentially form a gravel lag layer

$$
p_{\mathrm{L}, \mathrm{t}}=p_{\mathrm{A}, \mathrm{t}}-f_{\mathrm{g}, \mathrm{A}, \mathrm{t}}
$$

This value is used to compute the potential gravel lag layer thickness per unit width and length in the channel bed deposit. Assuming that a gravel lag layer consists of gravel only $(p=1)$, the thickness $L_{\mathrm{G}}$ of the potential gravel lag layer can be computed as:

$$
L_{\mathrm{G}, \mathrm{t}}=p_{\mathrm{L}, \mathrm{t}} L_{\mathrm{A}, \mathrm{t}}
$$

This gravel layer is then deposited in the model at depth $\left(L_{\mathrm{A}, \mathrm{t}}-L_{\mathrm{G}, \mathrm{t}}\right)<\mathrm{z} \leq L_{\mathrm{A}, \mathrm{t}}$, so the final sorting in the model becomes then:

$$
\begin{gathered}
p_{\text {final }, \mathrm{z}, \mathrm{t}+\Delta \mathrm{t}}=p_{\mathrm{z}, \mathrm{t}} \quad \text { for } z>L_{\mathrm{A}, \mathrm{t}+\Delta \mathrm{t}} \\
p_{\text {final }, \mathrm{z}, \mathrm{t}+\Delta \mathrm{t}}=z \mathrm{~d} p_{\mathrm{z}, \mathrm{t}+\Delta \mathrm{t}} / \mathrm{d} z \\
=z p_{\mathrm{A}, \mathrm{t}+\Delta \mathrm{t}} /\left(0.5 L_{\mathrm{A}, \mathrm{t}+\Delta \mathrm{t}}\right) \\
\text { for } z<\left(L_{\mathrm{A}, \mathrm{t}+\Delta \mathrm{t}}-L_{\mathrm{G}, \mathrm{t}+\Delta \mathrm{t}}\right) \\
p_{\text {final }, \mathrm{z}, \mathrm{t}+\Delta \mathrm{t}}=1 \\
\text { for }\left(L_{\mathrm{A}, \mathrm{t}+\Delta \mathrm{t}}-L_{\mathrm{G}, \mathrm{t}+\Delta \mathrm{t}}\right) \leq z \leq L_{\mathrm{A}, \mathrm{t}+\Delta \mathrm{t}}
\end{gathered}
$$

in which equation (12) accounts for antecedent gravel abundance below the active layer, equation 
(13) the linearly distributed gravel that is sorted anew for time $t+\Delta t$, and equation (14) the gravel lag deposition $\left(p_{\text {gravel }}=1\right)$.

Obviously, the resulting distribution of gravel in the model does not conserve the mass of the gravel completely (errors of a few per cent), because it adds gravel to the sediment in the gravel lag layer but does not subtract this amount from the gravel abundance in the active layer. The reason is that no transfer function is known and has been specified for working down the gravel from the foresets to the lag deposits, and therefore it is not known how to subtract the lag gravel from the cross-bedded gravel units. This error does not propagate in the model, however, because the composition of the active layer $p_{\mathrm{A}}$ at $t+\Delta t$ is not computed from $p_{\text {final, }, \mathrm{t}, \mathrm{b}}$ but from $p_{\mathrm{z}, \mathrm{t}}$, in which this gravel has not yet been added. For future purposes of bedload transport and morphological modelling, mass must obviously be conserved.

\section{APPLICATION OF THE MODEL TO THE RIVER RHINE}

\section{Boundary conditions}

The sediment transport and vertical sorting of two recent discharge waves in the Waal branch of the River Rhine are roughly hindcast with the model. The exact form of the discharge wave is of lesser interest and was therefore generalized and smoothed: mainly the maximum discharge and the maximum attained dune height are of importance here. The first modelled discharge wave must be the largest previous discharge wave of the period of interest. This is because the sorting in the bed is reset at that time and the deposit is predictable as a singular upward fining cross-bedded set. For the Waal, the magnitude of the discharge wave of January 1995 (maximum discharge about $10000 \mathrm{~m}^{3} \mathrm{~s}^{-1}$ ) is chosen as a boundary condition. The next discharge wave was in November 1998 (maximum discharge about $6000 \mathrm{~m}^{3} \mathrm{~s}^{-1}$ ). During this event, extensive field measurements were carried out as described above. These measurements will be used to evaluate the modelling results. The initial average gravel abundance in the bed sediment in 1995 is $45 \%$, from the grain size analysis of the vibracores.
The model was implemented in a spreadsheet. The vertical grid spacing and time-step were chosen such that the change in lag deposit thickness is smaller than the grid spacing for all time steps to prevent unrealistic gaps in the lag deposits. In this case, a vertical grid spacing of $13 \mathrm{~mm}$ was used, which is about equal to the $D_{90}$ of the sediment mixture. Gravel lag layers thinner than $13 \mathrm{~mm}$ have been ignored. The time-step was 1 day.

There are no field data available of water depths and flow velocities for the whole range of modelled discharges. Therefore a readily available one-dimensional flow model of the Rhine branches was used to compute width- and depth-averaged water depth $(h)$ and flow velocity $(u)$ for a large range of discharges $(Q)$ in the Waal (A. Wolters, SOBEK-model, Rijkswaterstaat-RIZA, personal communication). This flow model has been calibrated on water levels at several stations along the river as well as discharge measurements over a large range of low and high discharges.

\section{Modelled flow parameters, dune height and bedload transport}

The flow velocity and grain shear stress follow the pattern of the discharge (Fig. 9a) as expected. The water depth is attenuated for a discharge above $8000 \mathrm{~m}^{3} \mathrm{~s}^{-1}$ owing to the flooding of the embanked floodplains, which leads to a sudden increase of the width of the river. In Fig. 9a the measured flow velocities of the second discharge wave are given, and are well reproduced by the model.

The simulated maximum dune height (Figs 9b \& 10a) in the second wave is somewhat smaller than the observed height. Note that, in the model, hysteresis is due to changing the algorithm for dune height, not due to a modelled dynamic effect. The predicted sand and gravel transport are in the same order of magnitude as the observed transport (Figs 9c \& 10b), but the trend is obviously totally wrong, and cannot be predicted with this model for reasons mentioned earlier.

\section{Modelled sediment sorting and lag deposits}

The modelled sorting in the bed is shown in Fig. 11(a \& b). During rising stages and at peak flow, a thin gravel lag layer formed in the dune troughs and moved downwards in the bed as the 

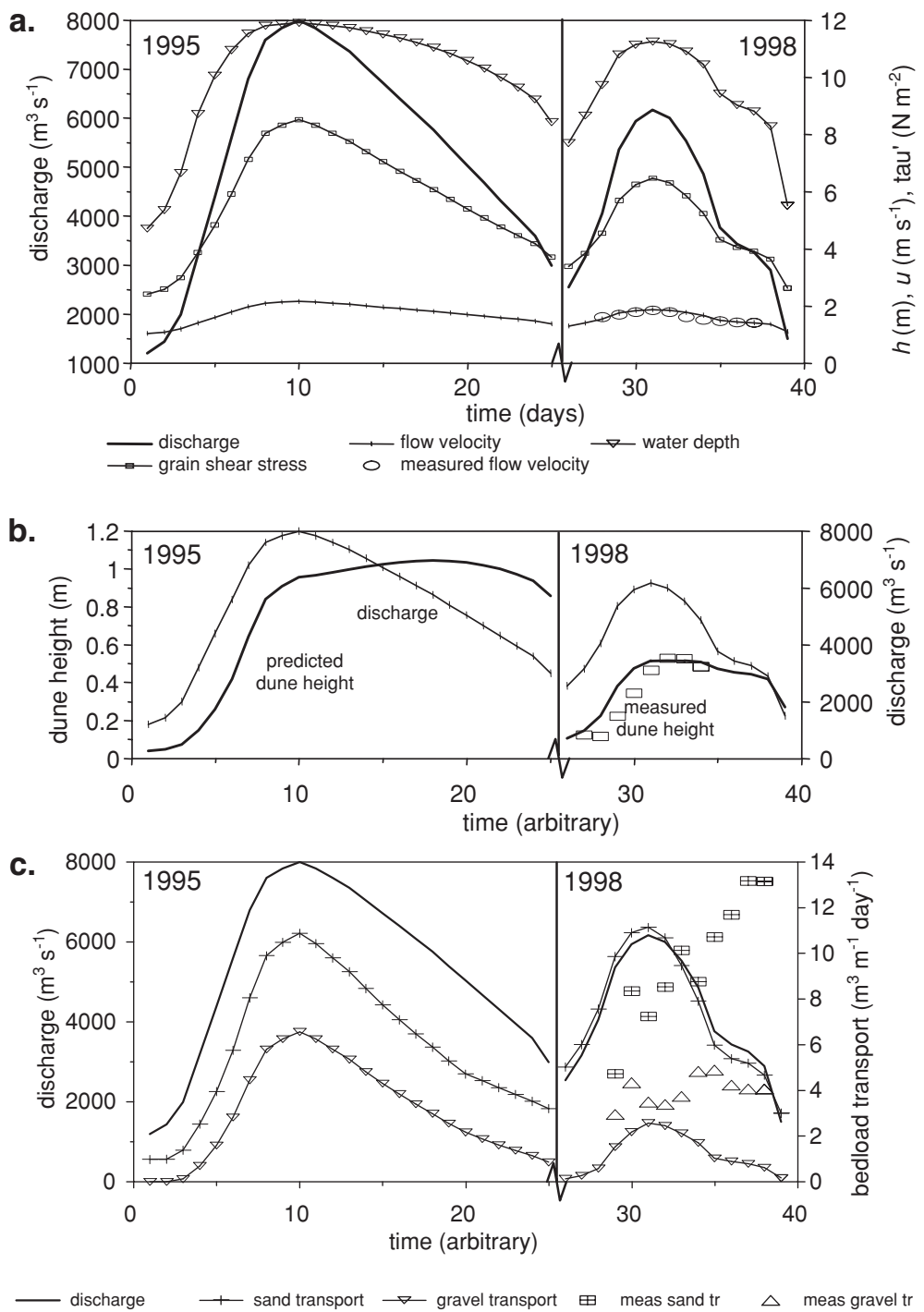

Fig. 9 (a) Discharge, water depth, flow velocity and grain shear stress, as well as the measured velocities. (b) Dune height, as well as the measured dune heights. (c) Bedload transport of sand and gravel, as well as the measured transport (using Helley-Smith-type bedload sampler).

dunes grew until peak flow. These thin layers result from the intrinsic difference between active layer sediment and predicted bedload sediment with the bedload predictor, as explained earlier. In falling stages, the modelled gravel lag became thicker at $0.4-0.5 \mathrm{~m}$ below the bed surface. During the second discharge wave, the same pattern was found with a gravel lag layer at $0.2-0.25 \mathrm{~m}$ below the bed surface, except that it was thinner. An important observation is that the potential for gravel lag formation is largest during falling stage. The reason is that during falling stage the bed shear stress is decreasing, which leads to increasing demobilization and deposition of the larger grain sizes, while the dune height is still increasing.

The predicted, reach-representative sorting agrees with the results from vibracores from the Waal, in which also two layers could be found at depths of about 0.3 and $0.7 \mathrm{~m}$ that were the result of the discharge waves of 1995 and 1998 (Fig. 6). The difference in depth of the gravel layers is related to small errors in the dune height predictions. These could be adjusted arbitrarily to improve the predictions, but the essential feature of the vibracores reproduced here is not the exact 


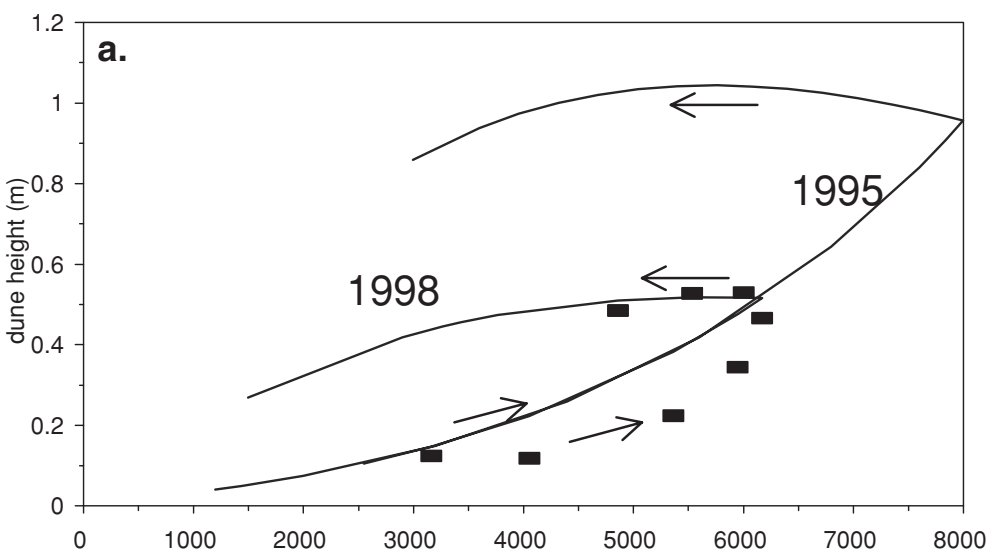

Fig. 10 (a) Dune height and

(b) sediment transport as a function of discharge. Both the predictions (lines) and the measurements (symbols) show a strong hysteresis. The bedload transport as measured with the sampler increases even further in the falling stage, while the bedload transport determined with the dune-tracking method decreases. The predicted bedload transport curve for 1998 lies higher than for 1995, which is caused by the antecedent sorting from 1995 (which itself had not had antecedent sorting included in the model).

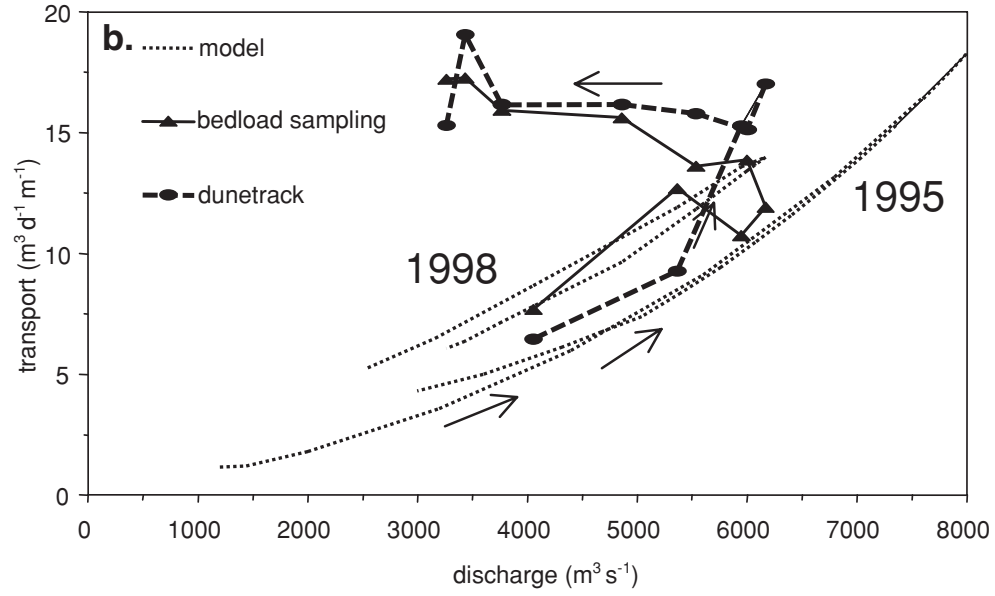

Fig. I I (right) Model output: the final sorting of the river bed after the first two discharge waves (a \& b). A gravel lag in the dune trough sinks into the bed as the dunes grow. In the falling stage, a much thicker gravel lag is formed. In the second discharge wave the same happens, but at a shallower depth. The lines have been given small offsets to be able to distinguish between different steps. Compare with Fig. 6.

a. High discharge in 1995 gravel fraction

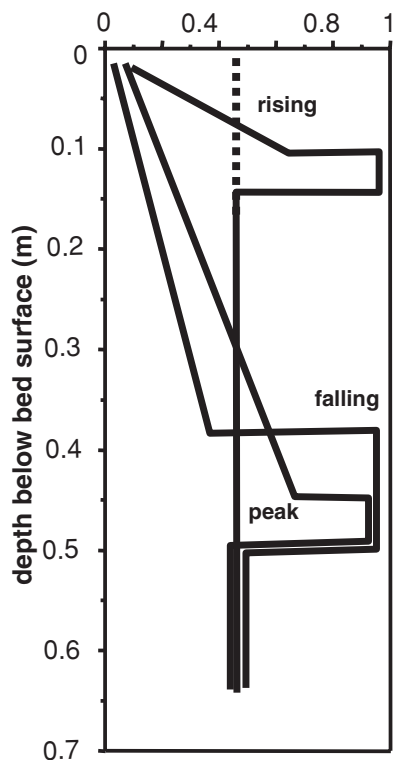

b. Low discharge in 1998 gravel fraction

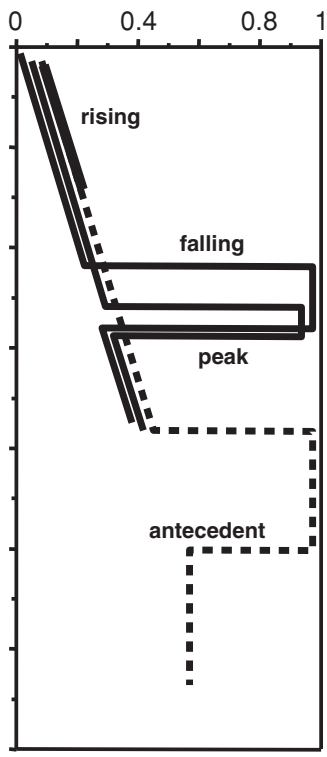


depth but the bimodality of the gravel distribution in depth.

\section{Sensitivity analysis}

For two parameters the sensitivity was roughly tested: the maximum dune height and the vertical sorting function.

1 The sensitivity to the maximum dune height for the results is marginal. When this maximum dune height is decreased or increased, then the active layer thickness and depth of the gravel layers decreases or increases with the same factor. The sensitivity to the dune height hysteresis was not tested, but a decreased hysteresis will have the effect that the potential gravel layers become less thick.

2 The vertical sorting function as given here has the largest slope possible, which means that a perfect sorting efficiency is assumed. When this slope is decreased by $5 \%$, then the gravel layers become thinner. Between 5\% and $6 \%$ decrease, the gravel layer of the second discharge wave disappears altogether. Thus the results are rather sensitive to the vertical sorting function.

Concluding, the model is able to reproduce the sorting in the river bed, and this sorting is genetically traceable to discharge events, but the sensitivity to the vertical sorting function is large.

\section{DISCUSSION}

\section{Effect of sorting function for cross-bedded (foreset) deposits}

The vertical sorting at the lee side of the dunes is assumed to be linear, therefore the transition from cross-stratified deposit to lag deposit seems rather abrupt in the model outcome, which is only partly supported by the field and flume data. In the present model, the sorting is maximal in the sense that it yields the least possible gravel abundance in the top layer, and the maximum possible gravel abundance in the bottom layer. It could well be that the sorting within grain flows in nature is less effective than assumed here. As shown in the sensitivity analysis, this would lead to a less clear sorting in the cross-bedded deposits. At the same time, if the gravel accommodation in the top part of the active layer was higher in falling stage, then the potential gravel lag deposits would be thinner or vanish altogether (see section on sensitivity analysis). Concluding, the sorting in the active layer depends greatly on the vertical sorting function. Yet, the most straightforward parameter choices and assumptions give reasonable results, indicating that the conclusions herein are at least in the direction of what may be found with further research. To be able to predict the sorting for more than two grain-size fractions, a quantitative predictor must be found for the vertical sorting in grain flows and due to selective deposition. The results of experiments by Kleinhans (2000; see also Blom \& Kleinhans, 1999), as given in Fig. 3, indicate that the sorting function deviates only slightly from linear and indeed comes close to zero gravel in the top of the dunes. Experiments to study vertical sorting (carried out at St Anthony Falls Laboratory in Minneapolis, USA) by Kleinhans (2002) also show that the optimal sorting does not deviate very much from a linear profile.

\section{Future model development}

The problems notwithstanding, the main asset of this model is that it demonstrates a possibility for the prediction of vertical sediment sorting by two processes. The model demonstrates that essential elements for the prediction of sediment transport and vertical sorting in rivers with dunes and sand-gravel mixtures are:

1 a vertical sorting function for equilibrium sorting in the foreset (cross-bedded) deposits;

2 a time-dependent approach to this equilibrium to account for the time necessary to deposit or entrain the gravel at the base of dunes;

3 a dune height predictor including a timedependent approach to the equilibrium dune height.

As a result, the model should be able to reproduce:

1 sediment transport hysteresis during a single discharge wave;

2 relative sediment transport differences between successive discharge events (for the same discharge);

3 secondary, sandy cross-stratification (infilling of dune troughs with sediment from the tops of 
these dunes) in the case of strong dune height hysteresis, in addition to primary cross-stratification and lag deposits, and their relative abundance in the channel bed for different dune height adaptation time-scales.

\section{CONCLUSIONS}

River channel bed deposition of sand-gravel mixtures is strongly coupled to dune development and the sorting of sediment in the grain flow at the lee side of dunes, as well as grain-size-selective deposition in the dune troughs (gravel lags). Data from the River Rhine clearly indicate that vertical sorting is generated in the river bed down to a depth depending on the maximum (reach-averaged) dune height attained in a discharge wave.

Consequently, strong feedbacks between bedload sediment transport rate and composition versus deposition in the bed are expected. The bedload sediment transport rate and composition are dependent on the sediment in the active layer (down to the dune troughs), which is determined by the sorting in previous events. The deposits on the other hand are governed by the selective transport and by sorting in dunes, as well as the dune height development during a discharge event. Consequently, the vertical sorting of previous discharge waves may cause hysteresis of the sediment transport, which can only be hindcast by incorporating this sorting.

The process model developed in this paper is able to reproduce the main characteristics of vertical sorting in the bed of the River Rhine resulting from two recent discharge waves. This approach should be seen as a first exploratory attempt to model vertical sorting. The model shows that both vertical sorting resulting from grain flows on the lee side of dunes and from selective deposition play an important role in the sediment transport and deposition of sand-gravel sediment. The dune height adaptation to changing flow and dune celerity determine the ratios of lag deposits and cross-stratification. The deposition of gravel lag layers in the bed occurs mainly during falling stage, because the grain shear stress is then decreasing while the dune height is still

increasing. Sediment transport is not correctly predicted with this model, however, because the phenomena that cause strong transport hysteresis were not included in the model. The order and magnitude of discharge waves are important, as the largest wipes out all antecedent sorting, whereas the processes in smaller ones depend on the depositions of previous waves.

\section{ACKNOWLEDGEMENTS}

The present research is part of a $\mathrm{PhD}$ research programme at Utrecht University on sediment transport and dune behaviour in sand-gravel-bed rivers during high discharges. The investigations were in part supported by The Netherlands Earth and Life Sciences Foundation (ALW) with financial aid from The Netherlands Organization for Scientific Research (NWO). The National Institute for Inland Water Management and Waste Water Treatment (RIZA) and the Directorate Eastern Netherlands of Rijkswaterstaat in The Netherlands financed and carried out the measurements in the rivers Waal and Bovenrijn, as well as the vibracores (in cooperation with the Dutch Institute for Applied Geology (TNO-NITG). RIZA is gratefully acknowledged for the permission to use the vibracores. Antoine Wilbers (Utrecht University) is thanked for providing the dune statistics from the multibeam echo soundings. The flume experiments were financed by (i) the Transport and Mobility of Researchers Programme of the European Commission and (ii) the consortium of Twente University, The Institute for Inland Water Management and Waste Water Management (RIZA) and WL Delft Hydraulics. Ard Wolters is thanked for providing the SOBEK model output. Thoughtful comments by Janrik van den Berg, Leo van Rijn, Suzanne Leclair, Gary Parker and the manuscript reviewers John Bridge and Mike Church were much appreciated. Some views in this paper, however, do not agree with those of the manuscript reviewers, notably the role of the deepest dune trough scour depth and the dune migration velocity in the vertical sorting. More complete analyses of the present dataset in non-uniform sediment and also of existing datasets in more uniform sediment (currently underway) are deemed necessary and might change some of the presented interpretations in the future. 


\section{NOMENCLATURE}

C Chezy coefficient $\left(\mathrm{m}^{0.5} \mathrm{~s}^{-1}\right)$

$D \quad$ grain size (m)

$f_{\mathrm{i}} \quad$ fraction of grain size $i$ in bedload sediment

$g$ gravitational acceleration $\left(9.81 \mathrm{~m} \mathrm{~s}^{-2}\right)$

$h \quad$ water depth (m)

$H$ dune height (m)

$k_{\mathrm{S}} \quad$ hydraulic roughness (m)

$L_{\mathrm{A}} \quad$ thickness of active layer

$L_{\mathrm{G}} \quad$ thickness of gravel lag layer

LSB low-stage bed level (plane bed)

$p \quad$ probability/abundance of grain size fraction (100 times $p$ yields $p$ in \%) (-)

$q_{\mathrm{b}} \quad$ bedload transport $\left(\mathrm{m}^{3} \mathrm{~m}^{-1} \mathrm{~s}^{-1}\right)$

$Q \quad$ flow discharge $\left(\mathrm{m}^{3} \mathrm{~s}^{-1}\right)$

$T$ relative excess shear stress parameter:

$\left(\tau^{\prime}-\tau_{\mathrm{cr}}\right) / \tau_{\mathrm{cr}}(-)$

$t$ time coordinate

$u \quad$ flow velocity $\left(\mathrm{m} \mathrm{s}^{-1}\right)$

$z \quad$ depth coordinate, $\mathrm{z}=0$ at LSB

$\theta \quad$ Shields parameter (subscript 'cr' refers to critical Shields parameter) (-)

$\xi \quad$ hiding-exposure coefficient (-)

$\rho \quad$ density (subscript 's' refers to sediment)

$\left(\mathrm{kg} \mathrm{m}^{-3}\right)$

$\tau \quad$ bed shear stress $\left(\mathrm{N} \mathrm{m}^{-2}\right)$

Prime (') indicates 'related to grains'.

Subscripts $i, 50,90$, etc. refer to grain-size fractions $i$ or grain-size distribution percentiles.

\section{REFERENCES}

Allen, J.R.L. (1963) Sedimentation to the lee of small underwater sand waves: an experimental study. J. Geol., 73, 95-116.

Allen, J.R.L. (1970) The avalanching of granular solids on dune and similar slopes. J. Geol., 78, 326-351.

Allen, J.R.L. and Collinson, J.D. (1974) The superimposition and classification of dunes formed by unidirectional aqueous flows. Sediment. Geol., 12, 169-178.

Blom, A. and Kleinhans, M.G. (1999) Non-uniform Sediment in Morphological Equilibrium Situations. Data Report Sand Flume Experiments 97/98. University of Twente, Rijkswaterstaat RIZA, WL/Delft Hydraulics, University of Twente, Civil Engineering and Management, Twente, $50 \mathrm{pp}$.

Boersma, J.R., Van de Meene, E.A. and Tjalsma, R.C. (1968) Intricate cross-stratification due to interaction of a mega ripple with its lee-side system of backflow ripples (upper-pointbar deposits, Lower Rhine). Sedimentology, 11, 147-162.

Bridge, J.S. and Bennett, S.J. (1992) A Model for the Entrainment and Transport of Sediment Grains of Mixed Sizes, Shapes and Densities. Water Resour. Res., 28, 337-363.

Carling, P.A., Goelz, E., Orr, H.G. and Radecki-Pawlik, A. (2000) The morphodynamics of fluvial sand dunes in the River Rhine, near Mainz, Germany. I. Sedimentology and morphology. Sedimentology, 47, 227-252.

Egiazaroff, I.V. (1965) Calculation of nonuniform sediment concentrations. J. Hydraul. Div. ASCE, 91, $225-248$.

Gruijters, S.H.L.L., Veldkamp, J.G., Gunnik, J. and Bosch, J.H.A. (2001) De lithologische en sedimentologische opbouw van de ondergrond van de Panner-densche Kop. TNO-report NITG-01-166-B, Utrecht, 41 pp. (In Dutch.)

Hunter, R.E. (1985) A kinematic model for the structure of lee-side deposits. Sedimentology, 32, 409-422.

Jopling, A.V. (1965) Laboratory study of the distribution of grain sizes in cross-bedded deposits. In: Primary Sedimentary Structures and their Hydrodynamic Interpretation (Ed. G.V. Middleton). SEPM Spec. Publ., 12, 53-65.

Klaassen, G.J. (1987) Experiments on the effect of gradation on sediment transport. Euromech 215 Colloquiem, pp. 127-146. Genova, 15-19 September.

Klaassen, G.J. (1991) Experiments on the effect of gradation and vertical sorting on sediment transport phenomena in the dune phase. Grain Sorting Seminar, 21-25 October, Ascona, Switzerland.

Klaassen, G.J., Ribberink, J.S. and De Ruiter, J.C.C. (1987) On the transport of mixtures in the dune phase. Euromech 215 Colloquiem, Genova, September 1519.

Kleinhans, M.G. (1999) Sediment Transport in the River Waal: High Discharge Wave, November, 1998. ICG 99/6, Netherlands Centre for Geo-ecological Research/ Utrecht University Physical Geography, Utrecht, 101 pp. (In Dutch.)

Kleinhans, M.G. (2000) The relation between bedform type, vertical sorting in bedforms and bedload transport during successive discharge waves in large sand-gravel bed rivers with fixed banks. Proceedings, Gravel Bed Rivers Conference 2000, 28 August-3 September, Christchurch, New Zealand (Eds T. Nolan and C. Thorne), Special Publication CD-rom of the New Zealand Hydrological Society.

Kleinhans, M.G. (2001) The key role of fluvial dunes in transport and deposition of sand-gravel mixtures, a preliminary note. Sediment. Geol., 143, 7-13.

Kleinhans, M.G. (2002) Sorting out Sand and Gravel; Sediment Transport and Deposition in Sand-gravel Bed Rivers. Royal Dutch Geographical Society, Utrecht, Neth. Geogr. Stud., 293, 317 pp. 
Kleinhans, M.G. and Ten Brinke, W.B.M. (2001) Accuracy of cross-channel sampled sediment transport in large sand-gravel-bed rivers. J. Hydr. Eng., 127, 258-269.

Kleinhans, M.G. and Van Rijn, L.C. (2002) Stochastic prediction of sediment transport in sand-gravel bed rivers. J. Hydraul. Eng., 128, 412-425.

Koeppe, J.P., Enz, M. and Kakalios, J. (1998) Phase diagram for avalanche stratification of granular media. Phys. Rev. E., 58.

Leclair, S.F. (2000) Preservation of cross-strata due to migration of subaqueous dunes. Unpublished $\mathrm{PhD}$ Dissertation, Binghamton University, New York.

Leclair, S.F. and Bridge, J.S. (2001) Quantitative interpretation of sedimentary structures formed by river dunes. J. Sediment. Res., 71.

Makse, H.A., Havlin, S., King, P.R. and Stanley, H.E. (1997) Spontaneous stratification in granular mixtures. Nature, 386, 379-381.

McLean, S.R., Wolfe, S.R. and Nelson, J.M. (1999) Predicting boundary shear stress and sediment transport over bedforms. J. Hydraul. Eng., 125, 725-736.

Meyer-Peter, E. and Mueller, R. (1948) Formulas for bed-load transport. Second Conference, International Association of Hydraulic Research, pp. 39-64. Stockholm.

Paola, C. and Borgman, L. (1991) Reconstructing random topography from preserved stratification. Sedimentology, 38, 553-565.

Parker, G., Paola, C. and Leclair, S. (2000) Probabilistic Exner sediment continuity equation for mixtures with no active layer. J. Hydraul. Eng., 126, 818-826.

Ribberink, J. (1987) Mathematical modelling of onedimensional morphological changes in rivers with non-uniform sediment. PhD thesis, Delft University, Delft.

Schans, H. (1998) Representativity of Measurements in between Groynes in 1996 and 1997 for the Whole River Waal. ICG 98/15, Netherlands Centre for
Geo-ecological Research/Utrecht University Physical Geography, Utrecht, 145 pp. (In Dutch.)

Southard, J.B. and Boguchwal, A. (1990) Bed configurations in steady unidirectional water flows. Part 2. Synthesis of flume data. J. Sediment. Petrol., 60, 658679.

Ten Brinke, W.B.M., Wilbers, A.W.E. and Wesseling, C. (1999) Dune growth, decay and migration rates during a large-magnitude flood at sand and mixed sand-gravel bed in the Dutch Rhine river system. In: Fluvial Sedimentology VI (Eds N.D. Smith and J. Rogers). Spec. Publs Int. Assoc. Sedimentol., 28, 15-32.

Van Rijn, L.C. (1984) Sediment transport, part I: bed load transport. J. Hydraul. Eng., 110, 1431-1456.

Van Rijn, L.C. (1993) Principles of Sediment Transport in Rivers, Estuaries and Coastal Seas. Aqua Publications, Oldemarkt, The Netherlands, 335 pp.

Wathen, S.J., Ferguson, R.I., Hoey, T.B. and Werritty, A. (1995) Unequal mobility of gravel and sand in weakly bimodal river sediments. Water Resour. Res., 31, 2087-2096.

Wilbers, A.W.E. (1998) Bedload Transport and Dune Development during Discharge Waves in the Bovenrijn and the Waal. ICG 98/12, Netherlands Centre for Geo-ecological Research/Utrecht University Physical Geography, Utrecht, 60 pp. (In Dutch)

Wilbers, A.W.E. (1999) Bedload Transport and Dune Development during Discharge Waves in the Rhine Branches, Echo Soundings of the Flood in November 1998. ICG 99/10, Netherlands Centre for Geo-ecological Research/Utrecht University Physical Geography, Utrecht, 60 pp. (In Dutch.)

Wilcock, P.R. (1993) Critical shear stress of natural sediments. J. Hydraul. Eng., 119, 491-505.

Wilcock, P.R. (2001) The flow, the bed and the transport: interaction in the flume and field. In: Gravel-bed Rivers V(Ed. M.P. Mosley), pp. 183-220. New Zealand Hydrological Society, Wellington. 